\title{
El animal profundo: perfil psicológico del hombre
}

\author{
Leopoldo Chiappo \\ Universidad Peruana Cayetano Heredia \\ Lima, Perú
}

Se trata de trazar un perfil psicológico del hombre. Es decir, encontrar un denominador común que permita definir psicológicamente a la especie humana. Sin embargo, se tropieza con la variedad inconmensurable de maneras de comportarse y modo de ser de los individuos y grupos humanos. Precisamente lo que caracteriza al hombre como especie y lo hace diferente de las demás especies animales es la enorme variedad diferencial entre los individuos y grupos que forman la especie humana, en contraste con la uniformidad de comportamientos entre los individuos de las otras especies animales. Sin embargo, además de la heterogeneidad individual encontramos en la 'profundidad' la característica universal que, en grado mayor o menor, caracteriza al hombre.

animal profundo / antropología psicológica / motivación humana

\section{The profound animal: psychological profile of man}

The article attempts to outline a psychological profile of mankind. That is, to find a common denominator that will permit to psychologically define the human species. In this defining process, however, one encounters immeasurable varieties of forms of behaviors and ways of being among individuals and groups. Precisely what characterizes man as a species and makes him different from the rest of animal species, is the enormous differential varieties among individuals and groups that constitute the human species. This is in contrast with the uniformity in behavior among the individuals of other animal species. However, besides this individual heterogeneity, we find in "profoundness" the universal characteristic that, in different degrees, distinguishes men.

profound animal / psychological anthropology / human motivation

Dirección del autor: $\quad$ Universidad Peruana Cayetano Heredia. Centro Cultural Honorio Delgado.

Av. Armendáriz 445, Lima 18, Perú.

Persona 2, 1999, 33-78 
¿Qué dice la psicología sobre el hombre? ¿Qué podemos aprehender sobre el hombre en cuanto tal desde un punto de vista psicológico? ¿Es que tal aproximación con la psicología usual es posible? Es claro que el tema se abre en múltiples direcciones y que las preguntas formuladas suscitan diversas y controvertibles respuestas.

Por un lado, tenemos la variedad casi infinita de seres humanos. Bien lo decía el sagaz y sabio jesuita español del siglo XVII Baltasar Gracián, hombre reflexivo y conocedor de los hombres. "Visto un león, están vistos todos y vista una oveja, todas; pero visto un hombre, no está visto sino uno y aún ese no bien conocido". Frente, pues, a la casi total homogeneidad de los individuos de cada especie animal nos encontramos que precisamente la especie humana se caracteriza por la variedad de los que la integran, sus contrastes y las diferencias cualitativas, su escala de diferentes niveles, la asombrosa heterogeneidad del animal humano.

Trazar un perfil psicológico del hombre... sí, pero ¿cuál de los perfiles? Y aun así, supuesto un perfil típico, tomándolo del común de los hombres, o si se quiere, un perfil arquetípico, es decir tomándolo de las personas cumbres, tropezamos con lo arcano del hombre, pues no llegamos a penetrar el fondo de los demás y hasta somos desconocidos para nosotros mismos. Variedad y misterio del animal humano. Parece que estas dos características nos sustraen la posibilidad de diseñar un perfil psicológico único y completo. O, quizá, variedad y misterio sean los rasgos.

Y por otro lado, qué dice la psicología sobre el hombre. ¿Cuál psicología, cuál corriente, cuál doctrina, cuál escuela? ¿Será la psicología experimental, el psicoanálisis, la reflexología, el conductismo, la posición cognitivista, la corriente humanística y existencial? Más aún ¿será la psicología como disciplina abierta o, si se quiere, la restringida al método científico, sensu stric$t u$ ? ¿Acaso no nos podrá decir algo más y más profundo sobre la psicología humana precisamente el saber psicológico no científico pero sumamente sustancial, rico y jugoso acumulado gracias a la experiencia, la observación y la creación de los artistas, de los novelistas y poetas, de los dramaturgos, de los pensadores, de los biógrafos e historiadores? ¿Puede acaso desecharse el saber psicológico logrado en la meditación profunda y en la vida concentrada de los místicos o, también, en la experiencia y sagacidad de los hombres de mundo, avezados en la lucha de la vida y en el desencanto de la realidad humana?

Como puede verse, por esta introducción, el tema es en sí difícil y la metodología para abordarlo complicada y enorme. Es esto bastante para que mantengamos constantemente en la conciencia la intrínseca riqueza psíquica del hombre, lo fragmentario de su conocimiento y la multiplicidad de las apro- 
ximaciones psicológicas posibles. De tal manera tenemos que darnos clara y profundamente cuenta de la complejidad del psiquismo humano para que evitemos la caída en el dogmatismo de las escuelas que pretenden mostrar en su esquematismo un perfil psicológico único. Es lo que pasa con los esquemas que presentan los fanáticos secuaces de escuela, trátese de psicoanalistas, reflexólogos o conductistas. En todo caso, los métodos científicos rigurosos son insuficientes y se requiere aprovechar el saber de la vida psíquica accesible a los instrumentos hermenéuticos de las disciplinas culturales.

\section{UN ENCUENTRO HUMANO EN LA SOLEDAD DEL BOSQUE}

Vamos a asistir a un diálogo entre dos animales humanos. Ocurrió hace dos mil quinientos años. La conversación se desarrolló en una lengua hoy muerta para la sociedad, viva para los estudiosos, el pali. Ocurrió en el bosque a orillas del lago Gaggara, al norte de la India. Hemos de imaginarnos un lugar apacible, rodeado de altas montañas.

En el lugar hay una "comitiva grande" de animales humanos que escuchan atentos y que, en silencio, se han congregado en torno a uno de ellos que llaman "conductor del animal humano". Son los "bikkus", monjes mendicantes budistas. Estos animales humanos comen de lo que les regalan otros animales humanos. Son pacíficos y contemplativos. Los otros animales humanos, activos y luchadores, saben y se esmeran en procurarse el alimento en la lucha con otros animales no humanos y seres diversos, en la caza, en la pesca, en la agricultura, en el comercio, en la industria. Hoy, hace dos mil quinientos años, está de visita el hijo de un domador y mercader de elefantes, un joven atento, reverente y respetuoso, observador y cazurro, deseoso de aprender. Viene del "mundanal ruido" a la quietud del bosque, viene a contarle su experiencia de la vida al "conductor del animal humano", a Gautama, el despierto (Buddho), silencioso y suave, de rostro afable y despejado, y de labios benévolos y los ojos risueños, la mirada brillante y límpida que traspasa sin herir, una mirada que penetra y acaricia, una mente que comprende y que corresponde a un animal humano con las manos bellas, largas y tranquilas, los pies finos y delicados. Y Pesso, el joven hijo del elefantero, cuenta, afanoso, cómo así hay hombres torturadores de sí mismos y torturadores de los demás, cómo los hombres de una manera obran, de otra manera piensan y de otra manera hablan, cómo los hombres son así secretos, encubiertos, solapados; cómo así son hipócritas que saben decir lo que halaga y ocultar lo que no les conviene y que lo que han oído aquí lo repiten allá, y lo que han oído allá lo repiten aquí; cómo disimulan lo que piensan y fingen lo que no piensan, y cuán diferente lo que sucede con el elefante, que siendo un animal mañoso, sin embargo, cada vez que va y viene 
en la ciudad se hacen ostensibles a todos sus malicias, sus humores y sus caprichos. Y Pesso, el hijo del elefantero, culmina esta lamentable noticia sobre los hombres, que le ha dicho con noticioso aunque con afán angustioso, a Gautama, que ha escuchado sereno, inmóvil: "Porque impenetrable como la jungla, oh Señor, es el hombre, y abierto como la llanura, oh Señor, es el animal". A lo que Gautama asiente: “Así es, Pesso, así es: impenetrable como la jungla, Pesso, es el hombre y abierto como la llanura es el animal". Relato libre que hago de un pasaje del Discurso Li de la Colección Mediana del Hinayana publicada en "I Discorsi di Gotamo Buddho del Majjhima Nikayo" (I discorsi, 1925). Del texto tomamos las palabras de Pesso que repite Gautama.

\section{El ANIMAL HUMANO: SU PROFUNDIDAD}

Nos preguntamos: ¿Cómo así esta intrincada conducta humana, esta impenetrabilidad selvosa de la psicología del hombre? ¿Cómo así es que el animal más astuto y mañoso, se diría el animal más ladino resulta ostensible, "abierto como la llanura", a diferencia del hombre "impenetrable como la jungla"? ¿Cómo así se da el hombre, entre todos los animales, el animal hipócrita, es decir, el animal que oculta su verdadero juicio tras otro aparente que es el que muestra disimulando el verdadero y simulando otro que enseña, el falso?
Y es precisamente aquí que encontramos un primer elemento para trazar un perfil psicológico del hombre: su profundidad. El hombre, súbitamente, se convierte, a nuestra mirada, en un animal interesante, tiene espesor psíquico interno, tiene superficie y fondo. El hombre es un animal de trasfondos. El hombre puede ser un animal hipócrita porque es un animal profundo.

Explorar aquello en lo que consiste esta profundidad es lo que nos indica el camino que debemos seguir para llegar al hombre desde un punto de vista psicológico fundamental. Se trata de utilizar el método para trazar un perfil psicológico del hombre con el fin de superar las dificultades señaladas al inicio. La hondura del animal humano, su espesor psíquico, la dualidad de superficie y fondo constituyen la característica psicológica del hombre de carácter esencial y universal, aunque se da en grados diversos en los psiquismos concretos de los individuos de la especie. En verdad, en algunos la hondura es abismal e interesante, en otros lo es menos. Este es un primer hallazgo. Veamos con progresivas determinaciones su alcance tanto para el conocimiento del hombre como para un avance cualitativo en la disciplina.

\section{LA INTERMEDIACIÓN INTERNA:}

\section{PERSONA Y NÓESIS}

Entre el estímulo y la reacción, entre el impacto que viene del exterior a herir estimulantemente el organismo ani- 
mal vivo y provoca el disparo de sus dispositivos neuromusculares, el animal humano intercala lo que llamamos la disposición funcional noético-configurativa, lo cual le permite construir un mundo de objetos integrales llenos de sentido (y no un paquete de estímulos), un círculo humano de personas entre las cuales interactúa (y no meros impactos encadenados a reacciones) e, incluso, un mundo de símbolos, es decir, la cultura. Precisamente, la cultura debe entenderse de dos maneras: a) como un sistema de intermediación entre organismos humanos subsumidos en la instancia superior de personas $y$ a través de símbolos; y b) como un sistema de símbolos que contienen en forma elaborada connotaciones significativas e ideales de la experiencia humana y del conocimiento del mundo natural y humano, como el lenguaje, la religión, la ciencia, el arte, en suma el universo de las formas simbólicas (en el sentido de Ernst Cassirer). La palabra es el sistema paradigmático de símbolos a través de la cual los hombres se hacen confidencias que la naturaleza no entiende, confidencias filosóficas, religiosas, artísticas, científicas, políticas, económicas, jurídicas. Es un mundo interior que abre en el animal humano una profundidad inaccesible al animal no humano. Y el sistema de intermediación intersubjetiva que es la cultura constituye la morada del hombre a la cual los organismos psicofísicos por más evolucionados que sean no tienen parangón con los animales humanos. De tenerlo serían animales humanoides o, más bien, primates francamente humanos. Y en esto consiste la profundidad humana en lo que concierne a lo que en sentido amplio puede llamarse circuito recepción-acción, que vincula el organismo animal a su medio externo, en el continuum del cuerpo vivo en el mundo. El cuerpo del hombre, pues, es una caja de resonancia exquisita y amplia de lo que acontece en el mundo, algo así como "el espejo viviente del universo", para emplear la bella aunque un poco exagerada expresión de Leibniz. Digo exagerada con relación al hecho más frecuente que consiste en que los hombres suelen vivir en estrechos círculos de vida limitados a sus afanes, temores, ambiciones y pasiones egocéntricas, los cuales recortan el horizonte amplio universal, en la medida de sus alcances mentales e intereses subjetivos. Son pocos los hombres que alcanzan objetivamente a acercarse al inmenso universo y con ello a ser verdaderos "espejos vivientes del universo" en la maravillosa expresión del gran filósofo y matemático alemán.

En el circuito recepción-acción del animal humano por ser sujeto la persona y no el mero organismo psicofisiológico, por intercalarse el sistema noético-configuracional de símbolos, lenguaje, instituciones, etc., por abrirse la posibilidad personal de la libertad como proyecto existencial y libre albe- 
drío, no se puede hablar ya de estímulo-reacción, como quiere el mecanicismo behaviorista, sino de situación-respuesta. El hombre se enfrenta a situaciones en las cuales se le presenta una gama de posibilidades en la cual tiene que elegir una respuesta y de acuerdo o traicionando un proyecto existencial (Laín Entralgo, 1958; Zubiri, 1948). Es que el hombre no se encuentra de manera exclusiva con estímulos puntiformes, complejos de configuraciones meramente figurales sino con totalidades llenas de sentido gracias al acto de pensamiento que denomino disposición noético-perceptiva y que tiene la función de construir la estructura significativa del objeto dado así en el percepto (Chiappo, 1955, 1957, 1958). Es así como en el hombre se le ofrece un mundo de símbolos. En cambio, en el animal los datos sensoriales se estructuran como "señales" y en relación con meras apetencias y temores de carácter instintivo-afectivo que así lo incentivan (Cassirer, 1956).

Es necesario introducir en la psicología el nivel de experiencia psíquica y de conducta que podría llamarse nivel personal de la realidad psíquica integral de la existencia humana en cuanto tal. El error ha sido y sigue siendo considerar el organismo psicofísico despersonalizado como un aparato orgánico funcional que es asiento de dispositivos preparados genéticamente o instalados por aprendizaje y listos para dar una reacción unívoca mecánicamente elicitada. El hombre es persona que como jinete se monta sobre el organismo psicofísico y lo conduce según su capacidad de elaborar un proyecto intrínseco existencial de vida que llamo libertad; y que según su capacidad de decisión dirige sus acciones, no sólo las de efecto inmediato sino las de largo alcance, imaginando diversas alternativas. Se trata de un espesor psíquico que distancia al hombre de la chatura concreta e inmediatista del animal. Gracias a la encefalización progresiva en el phylum de los chordata y que en la rama de los primates está culminando en el hombre, la persona dispone de un organismo rico y plástico que le permite lo que llamamos espesor psíquico y profundidad. En este proceso de interiorización del psiquismo humano, su enriquecimiento se acentúa enormemente en relación con los demás primates y mamíferos, distanciándose larguísimamente de las aves, reptiles y peces, en la evolución del cerebro del homínido y de las otras especies de hombres; es un hecho muy reciente y rápido ocurrido en los tres últimos millones de años y en el caso del homo sapiens-sapiens en los últimos sesenta mil años. Lo que hay es un incremento del índice cefálico y en el sentido de la telencefalización de las estructuras y funciones del maravilloso cerebro, el trozo de materia más complejo que conocemos.

Es necesario insistir en que la complejidad de interacciones de los orga- 
nismos psicofísicos obliga a reconocer un nivel personal del psiquismo humano. En efecto, el organismo psicofísico se tiene, la persona se es. En verdad, la persona es el sujeto agente de las acciones, de las percepciones, de las experiencias, conductas y comportamientos del individuo. $\mathrm{Y}$ tal sujeto agente, la persona, es única, intransferible, irrepetible. El organismo psicofísico puede ser clonable; la persona no es clonable. Ricardo de San Víctor, pensador y teólogo medieval del siglo XII definió la persona como "incommunicabilis existentia" (véase Ricardus a Sancto Victore, De Trin. Capítulo 21, citado por el Aquinatense en Suma Teológica I, q. 24, art. 4, Tomás de Aquino, circa 1270). Es decir, la persona no puede darse en pluralidad de sujetos, no puede ser poseída en común por diversos sustratos, como sí es el caso de las propiedades específicas y las accidentales (ser tal árbol, el color verde, ser hombre, pero no ser este hombre que es la persona. Duns Scotus acertó cuando estableció como principio de individuación no la materia ("materia signata quantitate" de Tomás de Aquino), sino la estidad del individuo en la especie; técnicamente lo llamó "haecceitas" abstracto de "haec", este determinado individuo de la especie. Pero la "haecceitas" de Duns Scotus no es la "persona" de Ricardo, concepto solamente aplicable a la naturaleza divina ("persona est divina naturae incommunicabilis existentia") y por analogía a la condición de irrepetible, único, del individuo y del psiquismo humano. Es por ser persona que el hombre tiene una dimensión de profundidad. No así el animal que es puro organismo psicofísico.

\section{El CRÁNeo humano y los POETAS}

El índice encefálico es la relación entre peso-superficie del cuerpo y el peso-superficie del encéfalo. El enorme aumento relativo del tamaño del cerebro con relación al tamaño del cuerpo distancia a los mamíferos de los reptiles y peces, a los primates respecto de los otros mamíferos, y, espectacularmente, a la línea de los homínidos y la línea más cercana de los neoanthropus hasta llegar al actual homo sapiens-sapiens, respecto de las otras especies de hombres como el homo erectus, el arcanthropus, el paleoanthropus, los homínidos y los otros primates, los póngidos, los actuales grandes simios, ramas colaterales del homo y del homínido y hasta de los australopitecos, primates pero no simios. Este incremento ocurre en el sentido de la telencefalización por la cual las formaciones suprasegmentarias, es decir el cerebro, el neocortex, crecen y se complican en desmedro regresivo de las formaciones antiguas infrasegmentarias (el archipallium). "Este proceso de cerebración progresiva adquiere en el neopallium su maximum evolutivo, la dirección de esta evolución se realiza, según von Monakow y Mourgue, en el sentido del lóbulo fron- 
tal" (de Ajuriaguerra \& Hécaen, 1957). $\mathrm{Y}$ este aumento relativo del cerebro respecto del cuerpo del animal nos lleva a considerar lo que puede llamarse una mayor 'neuronización' de los órganos corporales, los cuales, entonces, cuentan con una mayor irradiación de terminaciones nerviosas por centímetro cúbico de tejido orgánico, especialmente en ciertas partes como los labios, los órganos vocales y las manos. Esto a mi juicio constituye la base orgánico-neural de la mayor y fina sensibilidad del ser humano, así como la mayor eficiencia de sus actos, especialmente con las manos. El mayor índice encefálico y lo que llamo la mayor y más fina y selecta 'neuronización' del aparato psicofísico son las bases materiales, biológicas, que responden a la 'personalización' del psiquismo humano. De allí la profundidad, la interiorización, el espesor de vida interior del psiquismo humano. La relación persona-aparato psico-físico es una relación sujeto-instrumento. Puede ser entendida como una relación estatua-fundamento. Son dos perspectivas que se complementan, siempre que se vean como concepciones descriptivas, no explicativas ni doctrinarias, como pretenden ser el espiritualismo y materialismo, respectivamente.

El cráneo es pues la caja que contiene este portentoso trozo de materia iluminada de consciencia superior que es el cerebro humano. Es así que el poeta Antonio Machado pudo exclamar asombrado: “ ¡Calavera vacía! ¡Y pensar que todo era dentro de ti, calavera!". Él ha hecho ver la esencia de la realidad psíquica, que envuelve la experiencia vivida, los pensamientos, imágenes, sentimientos, anhelos, pesares, alegrías y tristezas que resumidos en ese "todo era dentro de ti" han ocurrido dentro de la caja que hoy es sólo una caja vacía, una calavera. Y es que el acontecer de la vida psíquica, el acontecer de la consciencia ocurre dentro de una caja mineral de mil quinientos centímetros cúbicos de volumen para alojar una masa encefálica de apenas un kilo y medio de noble materia, asiento de la vida que se vive en su intensidad y problemas, y también en sus beatitudes y placeres.

Shakespeare (circa 1596-97) tenía consciencia aguda de lo asombroso del cerebro humano y por eso puso en boca de uno de sus personajes: "el cerebro, esa frágil morada del alma" (King John, acto V, escena VII). Y es por esa consciencia asombrada que Shakespeare le transmite ese asombro profundo y lúcido del animal humano inteligente a su personaje Hamlet (circa 1599-1600), quien en la escena en el cementerio frente a una calavera de hombre arrojada en la tierra exclama: “¿Dónde están ahora sus sutilezas y distingos, sus argucias y subterfugios y artimañas?". Y enterado de que se trata de Yorick, el ingeniosísimo bufón de la corte del rey, coge la calavera de Yorick y con su cráneo entre las manos re- 
cuerda: “ $¡ A$ Ah pobre Yorick! Yo le conocí, Horacio: era un hombre de una gracia infinita y de una fantasía portentosa..." ["a fellow of infinite jest, of most excellent fantasy...”] “¿Qué se hicieron de tus chanzas, tus piruetas, tus canciones, tus chispazos tan divertidos [your flashes of merriment] que hacían prorrumpir en carcajadas a toda una mesa" (Hamlet, acto V, escena I). ¿Podría decirse esto del cráneo de una vaca, de una gallina o de un lagarto? Se trata de la hondura psíquica del hombre frente a la chatura mental animal.

Dante exclama como así "del profondo de la testa" brilló en los ojos del amigo el fulgor del reconocimiento en un episodio en que se expresa claramente la mirada cargada de vida psíquica que emerge de la profundidad de la cabeza (Alighieri, Purgatorio XXIII: 40-48). Qué diferencia hay con la chatura frecuente en la mirada de los animales. La mirada humana tiene hondura y esta hondura le viene de ser persona, sujeto de valores espirituales que trascienden los meramente vitales del animal. Se trata también del ennoblecimiento progresivo de su linaje evolutivo que lo ha provisto de un sistema neural complejo y refinado en su estructura y funcionamiento. Por eso el cráneo humano es una caja repleta de maravillas. Nuestro cerebro telencefalizado es el mejor regalo que hemos recibido de la naturaleza. Y el ser persona, la más alta distinción en divino ennoblecimiento de nuestra existencia humana. Se trata de percibir en el fondo el alma de la vida que es la vida del alma.

\section{El PENSAMIENTO SIMBÓLICO Y LA} PROFUNDIDAD DEL PSIQUISMO

\section{HUMANO}

Hay que reconocer que en el hombre sobreviven en el circuito recepciónacción circuitos cortos estímulo-reacción montados sobre dispositivos más o menos mecánicos, directos e inmediatos y que son los reflejos (reflejos pupiliano, rotular, patelar, palmar, etc.; incluso en el recién nacido el reflejo de Babinski, que desaparece con la progresiva mielinización del sistema nervioso). En el animal no-humano el circuito corto y directo estímulo-reacción puede ser ampliado a niveles de reflejos condicionados e incluso a complejos niveles estimulantes del tipo "señales" que el animal ha aprendido a discernir e incluso descubriendo y realizando "operaciones de rodeo" por las cuales el animal supera el impedimento que se interpone entre su organismo y el objeto apetecido. El grado de elaboración de una "operación de rodeo" puede llegar incluso en algunos animales "inteligentes" e intensamente motivados por pulsiones orgánicas de deseo o de temor a apartarse del objetivo alejándose de él precisamente para encontrar el atajo que lo lleve a un objetivo que sin este detachment no sería jamás alcanzado. Se trata de que el camino recto entre dos puntos no es el más corto $y$, en cambio, mucho más viable pue- 
de ser la sinuosa operación de rodeo. Hay el caso de animales que quedan inmovilizados en el impedimento intercalado por no poder evitar la visión extática del objetivo apetecido y por tanto lograr la vía de rodeo por la que precisamente alejándose del objetivo sería el modo como el animal puede llegar al objetivo. Pero en este asunto de recepción-acción lo que le da al hombre profundidad, en el continuo cuerpo vivo-ambiente físico, en el continuo cerebro-nóesis-entorno, en la inserción recíproca de persona-mundo, es la intercalación iluminadora del símbolo, es decir, de la cultura. La conducta simbólica es específicamente humana según lo ha mostrado con una masa impresionante de datos sobre todas las disciplinas de la cultura humana, desde el mito hasta la matemática, el filósofo Ernst Cassirer, verdadero "miroir vivant de l'univers".

¿Qué es el símbolo? La respuesta se basa en el estudio que hemos hecho de la obra de Ernst Cassirer sobre la filosofía de las formas simbólicas (Chiappo, 1997-1998), los trabajos de Kurt Goldstein (1944), y en mis propias investigaciones sobre la psicología y la psicopatología de la percepción, el pensamiento y el lenguaje con pacientes con lesiones orgánico-cerebrales, así como con pacientes esquizofrénicos, mediante mi test de configuración noético-perceptiva (Chiappo, 1955, 1957, 1958, 1959). Y así es que podemos establecer los rasgos fundamenta- les de la mentalidad simbólica, lo cual es característica del animal humano. La construcción simbólica, la simbólicopoiesis del pensamiento humano, tiene como rasgos fundamentales la desadherencia, el desapego, el desasimiento de lo particular, sensible, concreto, inmediato. Es el camino que no transita el animal y que en cambio le permite al hombre abrirse espacio para comprender objetivamente el mundo y operar con amplitud y largo alcance en el mundo. Este desasimiento de lo concreto le abre también al hombre el ámbito de la más alta espiritualidad y le permite pensar sobre temas fundamentales de hondura metafísica. Gracias al desprendimiento de lo concreto el hombre puede conformar estructuras de significación general, simbólica, que superen lo particular para abarcar lo universal. La disposición noéticoconfiguracional que subyace en la capacidad de construcción simbólica permite enriquecer de sentido el sustrato sensible de los perceptos. El pensamiento humano se da como una disposición noética configurativa abarcante, que luego se despliega en los procesos sucesivos de las formas de concepto, juicio y razonamiento. Es lo que en nuestras investigaciones descubrimos como disposición noética subnocional, y que es preconceptual, prejudicativa, preinferencial. Por ejemplo, la delusión esquizofrénica que es un grave trastorno del pensamiento no consiste en un trastorno del juicio, sino en un tras- 
torno de la aprehensión del mundo perceptivo por debilidad de la dirección noética que desconfigura los datos sensoriales ofrecidos en el percepto. El acto noético-configuracional en que consiste lo fundamental del pensamiento simbólico abre el mundo sensible a la presencia del mundo inteligible y así todas las cosas se muestran en su sentido propio y trascendental. Es como si la mente humana, gracias al acto noético-configuracional, estuviese dotada de una vara mágica que va encendiendo de luz significativa profunda e irradiante de sentido el mundo opaco, de las crudas sensaciones, puro material sensorial en bruto.

La operación simbólica de la mente es la llave que le abre al animal humano la prisión del inmediato contorno físico sensorial, enriqueciendo su relación con el mundo y permitiéndole el acceso a formas de aprehensión cognoscitiva y significativa cada vez más amplias y objetivas del universo, desde el cual misteriosamente ha surgido. Mediante la construcción simbólica es posible desasirse de la inmediatez de la situación concreta y liberarse en un horizonte abierto y que es el así conquistado marco de referencia abstracto-teórico en que florecen el pensar y el actuar humanos. No ha de suponerse que esta abstracción se desvincula necesariamente del mundo. Todo lo contrario, merced a la elevación abstractiva del pensamiento se puede abarcar y abrazar más mundo.
La disposición noético-configuracional, es decir, la capacidad mental humana de organizar la percepción y la acción a partir del pensamiento permite a su vez la apertura al ámbito de lo posible e hipotético, así como el acceso al nivel de la idealidad, desligándose de la imposición y constricción de lo ya dado y establecido en la realidad. Es así que la mentalidad noético-simbólica permite suponer alternativas puramente ideales a lo concreto real; planear prospectivamente preparando en una secuencia organizada acciones de largo alcance; controlar la efectuación inmediatista de los impulsos y pulsiones mediante la consideración interna noética, sea para suspender, posponer o cambiar de dirección la acción, siguiendo más las directivas noético-volitivas que plegándose a la presión instintivo-emocional del deseo o del temor, liberando, así, experiencias y conductas de mayor riqueza significativa, mayor elegancia y refinamiento, más elevado nivel espiritual. Gracias a la mediación noética que permite que la persona pueda considerar in mente sus vivencias, sus conductas dirigidas y comportamientos efectuados, el hombre puede alcanzar una más alta jerarquía espiritual y una más profunda significación existencial respecto de todas las otras unidades vivientes.

\section{LA VIDA ERÓTICA Y LA POESÍA: PROFUNDIDAD HUMANA}

Una ilustración de este enriquecimiento noético que da lugar a la pro- 
fundización vivencial del escenario del mundo sensual nos lo puede dar la conducta erótica que acontece como experiencia de transfiguración del sexo animal al humanizarse en forma sublime. Del estímulo-reacción elemental e inmediatista constreñido al estro, propios del primitivismo del sexo entre los animales, el hombre, el animal profundo, inventa las formas más exquisitas y refinadas de amor. En esto puede dar testimonio encantador, y para poner un ejemplo histórico documentado, los modos de conducirse de las damas y las creaciones poéticas y musicales de los trovadores, así como las "cortes de amor" que florecieron en la paradisíaca región meridional de la Provence y también en Poitiers, en Troyes y en el Languedoc en el siglo XII. Son estas manifestaciones del amor secreto un verdadero florecimiento de la vida erótica intensa y profunda, verdaderas flores de poesía y de música que brotaron al borde de la inspiración y de las formas dulces del arte y de la creación musical refinada, y en contraste y como compensación de una sexualidad impuesta y fría, pisoteada por su supeditación a las costumbres matrimoniales ligadas a pactos políticos, negocios y obligaciones feudales. Los poemas, las canciones y el "amor cortés" han inmortalizado los nombres de las bellas mujeres que participaron en esta redención del amor cautivo, redención que se manifestara en una sensualidad, intensa, oculta, refinadamente desper- tada por la fuerte seducción del arte y que ha hecho noblemente famosas a Marie de Champagne, Eleanor de Aquitaine, Ermergarde de Narbonne, Isabelle de Vermandois y a excelsos poetas y músicos como Giraut de Borneil, Arnaut Daniel, Bernard de Ventadour, Jaufré Rudel, Bertrand de Born. El tosco marido feudal, guerrero y hombre rapaz instala la deuda sexual que le debe la esposa por pacto matrimonial, motivado por intereses políticos y económicos. El acto sexual para la esposa pactada no es más que el cumplimiento de una obligación, el pago de una deuda al marido acreedor indelicado y muchas veces violento, en todo caso exigente. A la torpe necesidad orgánica la fría imposición de la norma social. La mujer cumple a desgano un deber y el marido desfoga unas ganas. $\mathrm{Y}$ es en estas condiciones que el animal humano ha instalado una dominación social sobre una pulsión biológica. Pero el animal humano es profundo.

La chatura de una sexualidad primaria impuesta, rutinaria y obligatoria, tiene que ser sustituida por el relieve profundo y encantador de la elaboración cultural del sexo. A la inmediatez del sexo animal el hombre intercala todas las vivencias y formas intermedias de la espera, del cortejo, del diálogo y, como decimos, de la poesía y de la música. Elio Donato, interpretando el arte de amar de Ovidio y en su comentario sobre Terencio, señaló desde el siglo IV para la Edad Media, la secuencia del 
proceso amoroso: visus (primero la mirada, es el encanto extático, lo imagino, de la visión atrayente del aspecto de la persona, la visión, es el coup de foudre, el deslumbramiento del rayo de la belleza); luego allocutio (la palabra, el hablar de comunicación y de entendimiento mutuo de espíritus, la conversación, la galantería y la caricia verbal, lo imagino, mutua); luego tactus (el contacto físico, no antes, que sólo sea delicado y aproximativo, suave y provocador, lo siento); osculum (el beso) y la coronación insustituible y que es la sublimación misma del proceso erótico en su objeto propio: coitus (el abrazo sexual). Esto ocurre en la alcoba de la amada, quien a todos los esfuerzos, sufrimientos, canciones, proezas que ha hecho el amante le otorga, al fin, el consolum de sus aflicciones, la plenitud dulce e intensa del abrazo. Y todo esto en intimidad, todo esto discreto y sobre todo secreto, una dulcísima complicidad en y para el deleite sublime.

La apertura de profundidad psíquica que hace el hombre en la superficial experiencia biológica del sexo, se observa también en la capacidad de conversión de hechos naturales en símbolos psicoespirituales, incluso hasta en el canto de los pájaros, la alondra y el ruiseñor, que los jóvenes amantes Romeo y Julieta transfiguran sea en amables, sea en fatales, relojes ornitológicos, una, la alondra, que anuncia el fin del encuentro amoroso y los peligros del día que amenazan a Romeo y el otro, el ruiseñor, la nocturna posibilidad de prolongar, siendo ya de mañana, la noche de amor (Romeo y Julieta, acto III, escena V, Shakespeare, circa 1595-1596).

Es difícil de concebir en la chatura inmediatista del fenómeno biológico animal del sexo, cómo Bernard de Ventadour, amante de la lejana condesa de Triple en Syria le canta lo que llama "l'amour de loin", fórmula simbólica de una suerte de experiencia profunda, interior que tiene tanto de lánguida, suplicante como amorosa y respetuosa, para luego emprender viaje para llevarle ese canto de amor desinteresado y luego morir en sus brazos. Es en esta pura espiritualidad que aparece una de las formas de profundidad del hombre, en su experiencia transbiológica del amor erótico. Amor de deseo y de donación, eros y ágape. En el hombre el sexo adquiere profundidad. No sólo en la renuncia sino también, y muy especialmente, en la forma de realización concreta y directa del abrazo sexual de los amantes. En los ambientes cortesanos se fijaron "leyes del amor", que son las que hay que seguir, como lo que, ovidianamente, fijaba la secuencia que va del visus al coitus el gramático y retórico Elio Donato (mediados del siglo IV). Ya desde comienzos del siglo XII se establecieron estas leyes cuyo cumplimiento requiere la conducta amorosa cortés: mesura, servicio, proeza, larga espera, continencia, 
secreto y merced. Esta última era la coronación placentera, física, libre. Y así se ha logrado la "alegría de amor" (joy d'amor), que es el signo y la garantía de lo que en provenzal llamaban con justicia el Vray amor. La relación conyugal era triste y falso amor, dadas las condiciones de haberse constituido por razones políticas y económicas, previo pacto de las familias sin conocimiento y consentimiento de los interesados.

El amor cortés revela una faceta de la profundidad psíquica y espiritual del hombre. Es que, como vemos, consiste en una experiencia de enriquecimiento del impulso por la contención que implica su forma de realización, en la que, en este sentido, y según mi interpretación, hay que ver en la mesura, lo contrario a la impetuosidad indiscreta, extemporánea y violenta (es decir lo contrario de la vulgaridad); en la larga espera, la cual consiste en dejar que la pareja tome su tiempo de manera de no avasallarla o de exigirle prematuramente antes de que el deseo y la seducción hayan nacido y con ellos la acogida (esto es delicadeza y prueba de amor); en la proeza, por la cual el amante debe mostrar cualidades de valentía y de arte, rasgos profundos de denuedo y también de encanto artístico en la poesía y en la música y todo ello que despierte el interés y la estima de la amada (seducción del ser personal del amante; el amor cortés exige excelencia y excluye la mediocridad); servicio, disposición servicial en el sentido de estar disponible y hacendoso en atender o en haber atendido necesidades y requerimientos de la amada con desprendimiento y alacridad (prueba de amor); en la continencia, rasgo rey de la conducta amorosa cortés y que implica control de las pulsiones y elegancia, respeto y apasionamiento prometedor (nobleza de maneras, antichusquedad y no "castratismo"); en el secreto, que muestra el sentido caballeresco que inspira confianza a la dama y que es polarmente distante de la jactancia y de la indiscreción en las que nunca puede caer un hombre gentil y caballeresco. La merced, es la culminación del cortejo, tanto para la amada que la otorga como para el amante que al fin la recibe, merecidamente.

Como se ve, estas leyes del amor cortés que cumplidas llevan en sí mismas la "alegría de amor", constituyen marca fuerte del Vray amor. No son leyes represivas ni dictadas desde el poder, sino sugerencias del buen gusto, leyes de elegancia y seducción.

Hay una bella ilustración del "amor cortés" y muy estimulante respecto de la práctica de las "cortes de amor", los diversos casos, litigios y sentencias que en ellas ocurrían, en el libro De arte honeste amandi atribuido a Andreas Capellanus (escrito probablemente entre 1170 y 1174 con la intención de retratar la corte en Poitiers; Capellanus 1969). A mi juicio el capellán Andreas si no fue sino el amanuense, recibió 
muchas sugerencias y bastante del dictado de la gran dittatoressa de los asuntos del Vray amor Marie de Champagne. Con la definición del amor comienza el libro De arte honeste amandi, cuyo título expresa de qué clase de amor se trata: es un arte, una conducta cultural, aprendida, cultivada, no se trata del salvaje amor, forma usual, desmañada propia de los campesinos o de la gente palurda, tosca e ignorante, iletrada. Se trata de una práctica cultivada, refinada, elegante, encantadora y seductora. Este es el sentido de honeste amandi, lo que implica educación de la relación sexual entre personas cultas, cuyas exigencias de circunstancia y maneras son mayores y mejores, más delicadas y sugerentes, encantadoras, diferentes de los actos sexuales de los palurdos del campo. La palabra "honeste" no tiene significado moral sino estético. Es el mismo que tiene el soneto XXVI de la Vita Nuova de Dante cuando dice de Beatriz "Tanto gentile e tanto honesta pare / la donna mia cuando ella altrui saluta..." Si quisiéramos por contraste pensar en el antónimo sería "desfachada", "desgreñada", "descuidada", cuando honesta es elegante, atractiva, bien puesta, con gusto y primor exquisito, femenina, con gracia.

Digo que el libro De arte honeste amandi empieza preguntándose y contestando en breve y esencial definición "¿Qué es amor?" ¿De qué clase de amor se trata? Su origen y procedencia, sus efectos, cómo puede ser adquirido, retenido, acrecentado, disminuido y terminado. Cómo hacer para que el amor retorne y qué hacer cuando la pareja es infiel. Como se ve es todo un tratado práctico sobre el amor. Nos concentramos y sólo transcribimos la definición:

El amor es un cierto sufrimiento o pasión natural que adviene por la visión y la excesiva meditación de la belleza del sexo opuesto que causa sobre todas las cosas el deseo de abrazar y ser abrazado, y por el común deseo de llevar a cabo todos los preceptos del amor en el abrazo del otro.

Más adelante confirma:

Todo el intento de los amantes tiende hacia el gozo deleitoso de los abrazos mutuos y así con la esperanza de realizar plenamente los mandatos del amor.

Se trata de una efectiva sublimación de la actividad erótica. Sublimación en el sentido de elevar a lo más alto de la manera culta de efectuar el sexo en la dimensión de la profundidad del animal humano. No se trata de "sublimación" en el sentido que empleó la palabra Nietzsche seguido por Freud, para el cual prefiero la palabra "sublimificación", que es la pretensión de aparecer como sublime lo que no es sino máscara y disfraz de lo que se considera ordinario y bajo. En mi concepto de sublimación no se trata de sustituir el término del acto sexual, no se trata de suplantar el objeto propio que es el coitus con un sustituto espiritual, sino de realizar la totalidad de la actividad erótica 
hasta alcanzar su objeto sexual en un nivel sublime por la capacidad de inventiva de formas que elabora el animal humano llevando la actividad sexual a una intensidad y refinamiento inusitado. Esto es la auténtica sublimación del psiquismo. Y esta es la profundidad que el animal humano abre a la vida sexual gracias a su incorporación en las formas, fantasías y delicadezas de la refinada cultura de personas selectas.

Andreas Capellanus en su definición habla de llevar a cabo los deseos según las "prescripciones del amor". Es que el impulso vital del sexo se inserta en el hombre dentro de una estructura conductual rica y compleja, de largo alcance y con dimensiones espirituales de cortesía y respeto, de encanto y seducción así como de arte, belleza y creación, todo ello lejos de las formas deshumanizadas del sexo que también pueden darse en los hombres zafios. Las formas del amor cortés emergen de un psiquismo profundamente inspirado por el eros, por el dios "amor". Así lo entiende Dante también en la Divina comedia cuando cita tres veces el "amor" como el "dios" que enamoró y unió hasta la muerte a Francesca y Paolo (Infierno V: 100-106). Y es por esto que nuestro capellán o quizá la misma reina Marie de Champagne o alguna de las damas como la reina Leonor de Aquitania encontró que la etimología de "amor" es "amus", que como quiere decir "anzuelo", significa "capturar" o "ser capturado", comparando la tarea de seducción de los amantes con la destreza del pescador con el señuelo, que atrae a los peces para que caigan presos del anzuelo en él escondido. Se trata de un arte de seducción encaminado a encender el deseo erótico que une intensamente, con vivencia auténtica, a los amantes. No se trata de la obligación conyugal contraída institucionalmente por los esposos por razones no eróticas. No es extraño entonces que la princesa Ermergarda de Narbone en un juicio de la corte de amor dictamine que la esposa no puede negar la merced al amante pretextando estar casada, salvo que, quebrando los preceptos del amor, tenga que quedar privada del fuego de amor para siempre, lo cual frente al gran fortunio que para la existencia es el amor, la renunciante infeliz cae en el pésimo infortunio del desamor gris. Se trata del encanto estético y de la fuerza del deseo erótico cuyo valor de sublimidad excelsa y de experiencia auténtica vivencial exceden a las obligaciones ficticias contraídas según la norma conyugal. Es que la profundidad del hombre en sus vivencias espirituales y eróticas abre formas de psiquismo profundo que se da como opción noble frente a la hipocresía de las superficiales relaciones instituidas por las convenciones mundanas.

La humanización del impulso sexual, fenómeno natural animal, a través de las formas y comportamientos del "amor cortés" (l'amour courtois), mediante la 
llamada "cortezia", que convierte el impulso y la actividad físicos en una prolongada, alta y fina secuencia de intensas y exquisitas emociones y expresiones, y que a través de este amor físico animal refinadamente humanizado eleva hasta las más altas excelencias de experiencia psíquica y espiritual a los seres humanos, y los ilustra y nos ilustra sobre la dimensión de profundidad que alcanzan los instintos vitales animales en el animal humano merced a la estructura cultural de formas simbólicas que se intercalan entre los impactos del mundo y la respuesta del organismo humano personalizado, el organismo psicofísico asumido por la persona, que le da profundidad simbólica y experiencial a sus actividades. De tal manera el circuito estímulo-impulso-reacción se enriquece en el hombre porque su disposición noético-configuracional elabora y por ende complejiza dicho circuito que en el nivel de acto reflejo o de estímuloreacción en el animal es elemental y corto, inmediatista, pero que en el nivel del animal humano se configura en estructuras de rica y significativa percepción del mundo y de respuesta plástica contenida (no impulsiva inmediata), libre, elegante y de largo alcance. Estas estructuraciones complejas y llenas de significado, estas estructuraciones de percepción y respuesta, de actividad humana, son estructuraciones noetizadas, es decir, cargadas de pensamiento y por ende profundas, inaccesibles a la chatura sensorio-motriz del animal.

\section{EL HOMBRE: ANIMAL CULTURAL}

El hombre es un animal cultural (Cassirer, 1956), un verdadero animal simbólico-poyético (un animal creador de símbolos), por tanto es un animal que aprende culturalmente gracias a que acumula de manera simbólica la experiencia personal y colectiva $\mathrm{y}$ transmite esa acumulación, transmite la experiencia acumulada y luego inventa y la perfecciona. La conciencia humana tiene espesor de experiencia y pensamiento porque el hombre es un animal alta e intensamente memorioso. El animal olvida y siempre tiene que empezar de nuevo el mismo repertorio de acciones, a través de los millones de años, como se ve específicamente en los insectos y en las aves. $\mathrm{Y}$ es así, en este sentido, que cuanto más insertos se encuentren los hombres en el ámbito de la alta cultura, más distantes se hallan de la bárbara tosquedad, del primitivismo burdo y de la rusticidad torpe de quienes están sojuzgados por los impulsos inmediatistas, así como de los comportamientos y las maneras de vivir incultos que caracterizan a los hombres escasamente modelados por la espiritualidad, que es el más alto nivel humano de existencia.

La percepción del mundo y la actividad humana por la intercalación de la cultura y por la noetización de la percepción sensorial y de la acción hacen del animal humano un animal profundo. Si por un instante imagináramos nuestro planeta sin hombres, veríamos 
inmediatamente un extenso campo de desolación. Por ejemplo, habría cesado el lenguaje del hombre. Y es que el lenguaje, que es el ruido que hace el animal humano y que, aunque apenas es una tenue agitación de aire en la masa enorme de la atmósfera terrestre, carga el peso sustancial del pensamiento, y así abre en el universo físico un abismo de interioridad profunda que no tiene la superficie de los otros ruidos de la tierra. Ausente el hombre y con el hombre ausente, silenciado el lenguaje del hombre, la interioridad borrada de la tierra -entonces convertida en un escenario vacío, sin protagonistas ni actores ni personajes-, sin el drama humano y su profundidad espiritual, sólo se oirían ruidos de viento y de mar, ruidos de ríos y de cataratas, de rocas que caen, de hojas de árboles que se agitan y de troncos que crujen, de animales de variados ruidos, todo ello trivializado en la chatura del no decir nada. Sería aún algo más triste: la vida del universo sin espectador humano que la sienta y que la exprese en las palabras, las "aladas palabras" del hablar del hombre. Los ruidos del universo serían sólo ruidos, sin significación ninguna. Es, pues, el psiquismo humano inteligente el que instala la profundidad en el universo. Y ello por su dimensión espiritual.

El hombre intercala el lenguaje entre su percepción y su acción. Por el lenguaje, tanto el verbal como las otras formas de lenguaje que es, en último análisis, la cultura, el hombre se ha convertido en un animal profundo y, además, por eso, en un animal complicado. La apariencia externa de todo animal no humano, trátese de pez, reptil, ave, mamífero o simio, se caracteriza por su chatura expresiva, su elemental interioridad casi fantasmal. Parecería que el animal no humano no tiene espesor psíquico, se trata a lo más de un psiquismo emocional a flor de piel sin hondura. El hombre, y esa es la maestría de los grandes pintores retratistas, tiene una fisonomía interesante, profunda. Resulta increíble que haya habido una tendencia en psicología de tanta audiencia como el behaviorismo, que haya negado sistemática, metodológica y ontológicamente la vida interior, el fulgor incluso del alma.

En suma, el circuito percepción-acción se caracteriza en el hombre por la mediación simbólico-cultural construida por la disposición noético-configuracional instalada en la especial organización de su cerebro telencefalizado y que por ello complica, amplía, enriquece, diversifica y profundiza el horizonte de su comprensión del mundo así como las raíces y formas de sus motivaciones y la psicodinamia de sus tendencias e instintos. $\mathrm{Y}$ a la estructura de la realidad se sobreagrega el nivel de la idealidad propio del hombre. Es, por ejemplo, el lenguaje el que le abre el ámbito de la filosofía y de la ciencia, el maravilloso lenguaje que le enciende el esplendor de la palabra poética. 


\section{EL PSIQUISMO Y LA MOTIVACIÓN}

La aproximación descriptiva que hemos hecho del modo de ser del hombre, caracterizado por la función de intercalar entre la situación en que se encuentra y la respuesta, todo ello en un nivel de inteligencia simbólica y dentro de una estructura de noetización que subsume la conducta (la cual incluye el proceso interno) y el comportamiento (el cual es la expresión y ejecución externa de la conducta), según la valiosa distinción del psicólogo Aníbal Meza, no nos ha dado sino una de las líneas de la profundidad del animal humano. Pero la profundidad se muestra más compleja aún y llega más hondo cuando pasando más adentro del punto de vista meramente descriptivo consideramos una perspectiva dinámica y comprensiva del psiquismo. Se trata de profundizar en cuáles son y cómo se entrelazan las motivaciones humanas. Se trata en suma de preguntarse qué es lo que mueve al hombre.

El buen conocedor de hombres es el que tiene la perspicacia de penetrar los encubiertos designios de la conducta ajena o propia. Descubrir la verdadera motivación que está oculta entre las esgrimidas aparentes o las que aparecen más visibles, allí está el quid del conocimiento de la conducta de los hombres. Respecto de la motivación se podría parafrasear un conocido refrán y decir "dime lo que realmente quieres y te diré quién eres". Pero el querer real, la auténtica motivación a veces es sola- pada o disfrazada por otra, incluso para la propia persona, el querer real, digo, suele no salir fácilmente a la superficie, entonces se repliega y permanece oculto para los demás, incluso para uno mismo. Y aquí entra lo que nos tiene que decir la psicología dinámica $\mathrm{y}$ comprensiva. Y la psicología dinámica suele considerar los factores psicogenéticos subyacentes a los fenómenos psíquicos manifiestos, los factores causales. Y la psicología comprensiva, los fines perseguidos, el telos que le da sentido a los actos psíquicos o al psiquismo en conjunto del individuo. Se trata de lo que resulta psicoplástico, la dinamia de las causas psicosociales, por ejemplo, que están ocultas al propio sujeto y que se revelan a los tests proyectivos del tipo del Tematic Apperception Test, de Murray. O, por otro lado, la teleología del psiquismo individual, sus valores, la jerarquía de los valores y las preferencias subjetivas de la estimativa. El test de Vernon \& Allport (1931-1932), basado en la tipología axiológica de Eduardo Spranger (1950), explora el estilo axiológico de la personalidad.

En suma, no basta describir; es necesario comprender al hombre. La caracterología describe, la psicología dinámica y comprensiva interpreta la conducta humana, la dinámica explicativocausal, los factores genéticos (endogenéticos o hereditarios, exogenéticos, sociales, como los que formaron la personalidad básica, los educativos), la 
psicología comprensiva, el sentido, el telos. Se trata de apoderarse de los motivos, de las tendencias, del sistema de los propósitos radicales del hombre y de la persona estudiada. Y en esto está el ser profundo de la persona humana: cuáles son sus radicales, por qué y para qué hace lo que hace. $\mathrm{Y}$ el acceso a estas raíces subterráneas es en extremo sutil, complicado y controvertido. Se trata del problema de la motivación o motivaciones fundamentales del psiquismo y de la conducta.

\section{LAS IMÁGENES DEL HOMBRE}

$\mathrm{Y}$ en esto del psiquismo y de las motivaciones hay varias y contrastadas imágenes del hombre. Por poco que nos pongamos a reflexionar sobre el gran "teatro del mundo", nos impresiona la observación de que la más frecuente sustancia motivadora de que están hechos los dramas humanos son el sexo, el dinero y el poder. Éstos son los más comunes ingredientes de los conflictos, de los argumentos motivacionales de los animales humanos capturados en sus círculos de vida. La vida sexual y sus ajustes y desajustes, los celos, el deseo, todo lo relacionado con eros atrae a los seres humanos y los lleva poderosamente en la vida y son fuente de placer y de sufrimiento, de delicia y de dolor. Y la avaricia, afán de retener lo propio; y la codicia, ambición de obtener lo ajeno, lo que puede llamarse la 'plutofilia', o mejor, la 'plutomanía', el amor desmesurado y la manía de las riquezas suelen ser motivaciones comunes y corrientes, preocupación y ocupación, a veces obsesiva, de los seres humanos. Es el dinero fuente de actividad y pasión; en todo caso, el dinero está en la cabeza y en el corazón de la mayoría de la gente, sea porque lo tiene y en demasía y quiere tener más, sea porque carece de él y lo necesita dramáticamente para vivir. Y el poder es un instinto primario que tiene múltiple y variada manifestación. Es foco encendido de competencia, lucha y rivalidad en el mundo del poder político y así suele ser más que poder espiritual de liberación de fuerzas adversas a la autorrealización y plenitud que, según Spranger (1950), lo hace sinónimo de libertad, en realidad voluptuosidad de dominación y expansión sobre los demás del dominio de hacer y decidir. Es el poder del capo, del mesnadero, del pandillero y también del político, astuto y sesgado que no tiene el poder como poder de servir para el bien común, sino el poder para poder servirse en beneficio propio y de los suyos relacionados para prebendas y otros disfrutes tan indebidos como codiciados.

En los hombres y mujeres comunes y corrientes la motivación frecuente es la búsqueda de placer y afán de seguridad y que arraigan en los dos sentimientos motores más presentes: el deseo y el temor. Ya de ello sentaba cátedra el festivo y picante Arcipreste de Hita, quien escudándose con travesura en la autori- 
dad del viejo y solemne Aristóteles, suma autoridad escolástica en el siglo XIV, escribía en su Libro del buen amor (1955) los siguientes versos alejandrinos:

Como dice Aristótiles (sic), cosa es verdadera,

El mundo por dos cosas trabaja: por la primera,

Por haber mantenencia; la otra cosa era

Por haber juntamiento con fembra placentera.

Como puede verse el Arcipreste ve en el placentero y necesario instinto alimenticio y en el también placentero y necesario instinto reproductivo los dos móviles fundamentales del esfuerzo y de la actividad humanos. Y claro, el primero, "el haber mantenencia", está vinculado con la seguridad de la vida, el temor de no sobrevivir a la penuria y a la escasez, el trabajo por el sostenimiento. Y el segundo se refiere no tanto a la reproducción cuanto al placer del sexo. En cuanto a esto, el Arcipreste, digno hijo de su siglo y de su nación, es machista. Habría que inventar un filósofo contemporáneo que invente la contrapartida feminista. Y no podría encontrarse alguien mejor que la reina del feminismo, pionera inteligente de los derechos del "segundo sexo", Simone de Beauvoir, a quien podemos atribuir la autoridad paralela a Aristóteles en estos versos paralelos a su vez de los del risueño Arcipreste:

Como dice Simone de Beauvoir, hecho es verdadero

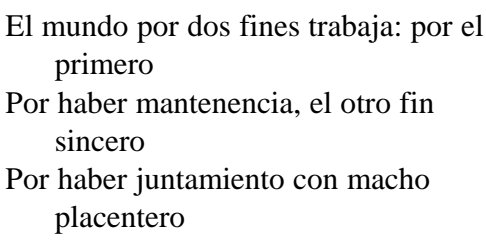

Pero hay otras imágenes del hombre. Por ejemplo, la que diseña y pinta con lucidez Maquiavelo. No es de esperar que la encontremos tan risueña como la de los dos Arciprestes, el machista y el feminista. Más bien una imagen psicológica, que en contraste con los altos ideales de Maquiavelo resulta apesadumbrada, la del hombre superior desencantado de la realidad de los hombres.

Maquiavelo pensaba y lo escribió: "en el mundo no hay sino vulgo" ("nel mondo non è se non vulgo"). Y estaba convencido de que el hombre es tal que primero olvida la muerte del padre que la pérdida del patrimonio, y por ello ofrecía el siguiente consejo al Príncipe:

Es mucho más seguro ser temido que amado... porque de los hombres se puede decir esto generalmente, que son ingratos, volubles, simuladores, huidores de peligros, codiciosos de ganancia.

Y esto no ocurría solamente en la corte del "magnífico" Lorenzo di Piero dei Medici, a quien va dedicado su libro Il Principe, pues quién no ha visto todos los días confirmarse esta observación de Maquiavelo: "Y los hombres tienen menos cuidado de ofender a uno que se haga amar, que a uno que se haga temer". Y Maquiavelo era un hombre fino y espiritual. Durante su exilio 
y confinado en una granja hubo de dedicarse a las duras faenas del campo. Desde la madrugada, todos los días trabajaba como labriego, y regresaba al atardecer a su mansión con las botas llenas de barro y el vestido sucio. Ya adentro se cambiaba y ya aseado se ponía su vestido de corte, y así trajeado con el lujo de una ceremonia cortesana Maquiavelo entraba a su biblioteca y así listo para recibir y ser recibido por los príncipes de la inteligencia, los gloriosos autores de los antiguos libros que, colocados sobre los atriles, se disponía a leer, y por ende a conversar con esos príncipes de la nobleza humana del saber, con Homero, Virgilio, Horacio, Ovidio, Cicerón, Séneca, Dante. Tal el respeto a la lectura como encuentro, ya no en la ceremonia palaciega con los políticos, diplomáticos, generales y personajes que solía recibir en su despacho de secretario de Estado, efímeros comediantes de la hora, sino en la íntima ceremonia de la lectura de los príncipes de la inteligencia, los autores de los libros eternos (véanse las cartas, para mí conmovedoras, ya en el exilio, del 9 de abril de 1513 y del 10 de diciembre del mismo año, a su amigo Francesco Vettori). Maquiavelo era indudablemente un fino psicólogo y hombre altamente espiritual, cuyo paladar exigente para catar la sustancia psíquica de los hombres le sirvió para escribir un libro que los retrata con realismo: la condición de la existencia humana deformada en el juego del poder,
Il Principe, y no, como se cree, un manual de maquiavelismo canallesco para políticos inescrupulosos, venales o sanguinarios.

Baltasar Gracián, jesuita sabio y sagaz, dos siglos después observaría: "Tratolos como ellos merecían y conociose bien, que con la gente vil obra más el rigor que la bizarría" (en este pasaje del Criticón "bizarría" significa "generosidad", lucimiento, esplendor en el matiz de la valentía y de la gallardía) (Gracián, 1941). Podemos completar este cuadro sombrío de la naturaleza humana recordando a uno de los más lúcidos psicólogos: Federico Nietzsche, quien en la duda de si todos los hombres, sean pusilánimes o cobardes, concluye que "los hombres son aún más perezosos que cobardes y lo que temen generalmente son los compromisos que les crearían la sinceridad y la lealtad absolutas" ("Consideraciones a destiempo: Schopenhauer, educador", sin fecha). Y dice respecto de lo que llama "escala de medida para todos los días: Rara vez nos equivocaríamos si nos decidiésemos a explicar las acciones extraordinarias por la vanidad, las vulgares por la costumbre y las pequeñas por el miedo" ("Humano demasiado humano", Aforismo 74). Es interesante vincular la explicación de las "acciones extraordinarias por la vanidad" de este aforismo con el Aforismo 1 del mismo libro, en el que formula Nietzsche su interpretación desenmascaradora de la "sublimación", en el 
cual por primera vez habla de este descubrimiento e interpretación psicológica profunda que, tomándolo de Nietzsche, utilizó Freud abundantemente para erigir los fundamentos de la interpretación psicoanalítica del psiquismo humano y su psicodinamia. Me parece muy probable que el puente que vincula a Nietzsche con Freud fue Lou Andreas von Salomé, inteligentísima y encantadora amiga y admiradora de ambos y admirada por ambos.

Efectivamente, en el Aforismo 1 de "Humano, demasiado humano" utiliza el fenómeno físico del paso de sólido a gaseoso de ciertas sustancias químicas, que se conoce con el nombre de "sublimación", para escribir metafóricamente de la "química de las ideas y de los sentimientos", por lo cual una materia sólidamente baja se gasifica al espiritualizarse, y siendo materia abyecta se "sublimiza", presentándose con una apariencia gaseosa noble. Es el famoso fenómeno al cual yo prefiero llamar "sublimificación", es decir, hacer sublime lo que no es sublime, usando una palabra que utilizó por única vez Honorio Delgado en su primer artículo sobre psicoanálisis, publicado en el diario El Comercio en 1915, y que quizá fue un error de imprenta. Efectivamente, para Nietzsche "las acciones extraordinarias" que realizan algunos hombres excepcionales tienen detrás de su "sublimidad" y, por ende, nobleza, una motivación vulgar, y, en consecuencia, vileza, como la vanidad, la cual, motivación sólida, real, se disfraza de acción extraordinaria al tornarse gaseosa, sublime. Es la vanidad misma de que están hechos los actos sublimes de los hombres. Los actos vulgares y las pequeñas vanidades no requieren disfraz, se presentan en su real ser, producto de la rutinaria costumbre y del miedo. No necesitan disfrazarse cuando no hay pretensión de grandeza, si sólo hay rutina y miedo, dos formas habituales del psiquismo vulgar.

La imagen peyorativa sobre el ser humano adquiere en Nietzsche sus tintes más oscuros cuando se refiere al sexo femenino, para cuyo trato recomienda el látigo, luego de haberse referido a su superficialidad y servilismo ("Also sprach Zaratustra”, diálogo con la anciana).

Nietzsche, sin embargo, considera peyorativamente el psiquismo humano como algo, producto de masificación colectiva y del devenir histórico, como puede verse en lo que él llama "el último hombre", el hombre de la plazuela, sin ideales, aburrido, nihilista, vulgar. Exalta las grandes individualidades del pasado como César, aunque encuentra siempre el talón de Aquiles en los personajes más venerados como Dante, Goethe, Wagner y otros incluidos en sus aventuras de mesnadero en que hace correrías aforísticas contra los "actuales", los ídolos que están de moda ("Streifzuge eines unzeitgemässen" ["Correrías de un inactual", diverti- 
mentos a costa de los que él llama "mis imposibilidades" en la Genealogía de la moral y en el Crepúsculo de los ído$l o s]$ ). El hombre actual, su psiquismo defectivo, debe ser superado y Nietzsche traza una imagen del hombre posible en el hombre dionisíaco (véase Chiappo, 1978: 108). La imagen del hombre dionisíaco es una feliz imagen del hombre con psiquismo iluminado por la fuerza, la energía y la embriaguez festiva de Dionisios; es el hombre libre que ha dejado atrás el espíritu de esclavitud servil y el espíritu pesado, es el hombre que ha superado al hombre actual. Se trata del que Nietzsche llama con una expresión muy malentendida "Uebermensch". No se trata del ario prepotente de los nazis, sino del hombre que ha superado al hombre pesado y convencional, y que, por tanto, diseña una nueva imagen del psiquismo humano más parecida al artista libre y fascinado por la Belleza y muy lejos del tirano prepotente. Es penoso que rara vez se haya entendido la proyección dionisíaca del psiquismo suprahumano.

Contrasta enormemente con las descritas y mencionadas imágenes sombrías del hombre (y que yo considero exactas en lo que atañe al hombre defectivo en cuya realidad fracasa el proyecto humano) con otras no menos realistas por ser radiantes y luminosas y que descubren en el animal humano una nueva hambre y una nueva sed. Es el hambre y sed por lo excelso, por lo excelente. Es hambre y sed que despiertan lo que yo llamaría una suerte de fino olfato para el infinito frescor de lo eterno, un oído afinado para percibir la "música callada" (San Juan de la Cruz 1980); ojos luminosos para penetrar la "tiniebla superluminosa" (Pseudo-Dionisio Areopagita, oscuro monje sirio del siglo V); un gusto para entrar en la "sobria ebrietas" (Gregorio de Niza, contemplativo místico capadocio del siglo III; Danielou 1953) o si se quiere un gusto capaz, para usar una expresión de nuestro gran poeta César Vallejo, de ir "saboreando un sabor ya sin sabor". Es que el hombre, este animal humano, inaugura en el planeta un nuevo instinto, lo que el Aquiniano llama maravillosamente el "instinctus divinus", el estímulo, el aguijón de lo divino (la palabra instinto incluye esencialmente la idea de aguijón, de punta irritante que suscita reacción, pues remonta al sánscrito tigmah, punteagudo). Se da en el animal humano como un salto de nivel espiritual del psiquismo animal pero se manifiesta este "instinctus divinus" como un aguijón que atraviesa a ciertas naturalezas personales individuales lacerándolas hasta las entrañas mismas. Y a veces este aguijón estimulante divino tiene la misma premura, y a veces aún mayor, que la sed, el hambre y el deseo físicos, y su punta (tigmah) acicatea en la aspiración a lo infinito y eterno, en la fascinación y la necesidad de belleza, en la investigación de la verdad, en la lucha por la jus- 
ticia, en la angustia metafísica. Y qué distinto de lo que nos decían Macchiavello y Gracián cuando San Francisco de Sales escribe que "los hombres hacen más por amor que por severidad y rigor" (1983) y Goethe: "Si tomamos a los hombres tal y como son los haremos peores de lo que son; en cambio si los tratamos como si fuesen lo que debieran ser, los llevaremos allí donde tienen que ser llevados" (citado por Frankl, 1957).

\section{Por Qué las imágenes \\ CONTRASTANTES DEL HOMBRE}

Pienso que el problema de las motivaciones fundamentales del hombre debe tratarse dentro de una teoría de desarrollo psicoespiritual. La naturaleza humana es contrastada y diversa. Los individuos raramente logran la armonía y menos la armonía fundamental, y frecuentemente viven desgarrados en contradicciones. Todo es de esperarse en el hombre. El error sería establecer como fundamento motivacional uno único y que suele ser el producto falsamente totalizador de una experiencia fragmentaria de la vida.

Precisamente, este es el error de los psicoanalistas que reducen las motivaciones humanas, unos al erótico principio del placer, otros al instinto tanático innato de agresión $\mathrm{o}$, los disidentes adlerianos, a la voluntad de poder. En verdad, cada nivel de desarrollo psicoespiritual de los hombres como personas tiene su sistema propio de moti- vaciones, así como en cada tipo de círculo de vida juegan distintos móviles, incluso en la misma persona. Uso el término "círculo de vida" (Nicolai Hartmann) de manera libre como estructura de relaciones inmediatas de carácter social que tiene la persona, ya sea en el hogar, el centro de trabajo, el club. El estilo del círculo de vida lo constituye el carácter de las relaciones interpersonales, el tejido de relaciones con los otros. En suma, el lector puede hacerse una idea de la variedad de estilos de círculos de vida si imagina círculos tan diversos como pueden ser los que aquí mencionamos: el del poder político, la corte, el Consejo de Ministros, el Congreso, el monasterio, el prostíbulo, la Bolsa de Valores, etc. Se trata de observar un fenómeno interesante: no sólo los sistemas de valores que señorean y dan la tónica colectiva de cada círculo de vida y del estilo de comportamiento que configuran en las personas que actúan dentro de él, sino de la manera de acomodar la respuesta experiencial y conductual de la persona en función de las personas diferentes que puede encontrarse en cada círculo de vida. No se trata, como dice Honorio Delgado, de que la persona tenga que poner en juego diferentes "persónulas", de que estaría hecha en forma abigarrada la unidad inescindible de la persona normal, sino que se trata de la riqueza, variedad y flexibilidad de la persona que es capaz de poner en juego la actitud, el sentimiento y la conducta 
adecuadas en cada situación, a la índole y momento del interlocutor con el que se relaciona. Hay personas rígidas que no tienen esa elasticidad actitudinal y la correspondiente consideración atenta al interlocutor y a la cortesía y maneras que merece. Imaginarse, para entender lo que digo, a un hombre que pertenezca a diversos y contrastados círculos de vida. Es de esperar que la persona tendrá que acomodar el estilo de su respuesta, su actitud y sus maneras, y de modo no advertido por él mismo, al ambiente requerido por cada círculo de vida.

Contrastan, por ejemplo, el círculo de vida doméstico que abre un sistema de relaciones afectivas de familiaridad y cariño con un círculo de vida relacionado con el trabajo, la diplomacia, la política, los negocios, la vida académica, en suma, la vida oficial de la persona, la que en cada caso debe acomodar su sistema de respuesta y de conducta a las exigencias del interlocutor. No se trata solamente de lo que en algunos casos nuestro animal profundo encubre y finge con hipocresía ex profeso el comportamiento adecuado a la situación. Se trata de algo menos dramático; se trata de que en cada círculo de vida en el que se está, se exige, según la situación diversa, adaptar, sin que la persona lo advierta en sí misma, la actitud y el comportamiento que se requiera de acuerdo no sólo con el estilo del círculo de vida sino con la naturaleza y sentido que tengan las relaciones humanas y emocionales, psicológicas, espirituales de la persona con las otras personas. De allí los contrastes motivacionales, que se acentúan según el nivel psicoespiritual que requiera el ser necesario que armonice con el carácter y el nivel psicoespiritual de la persona con quien se trata. Una persona de psiquismo sutil, sensible y dotado de lo que los franceses llaman souplesse, sabe mover atinadamente su actitud adaptándose con finura y acierto a los requerimientos situacionales y caracterológicos y temperamentales, $\mathrm{y}$ al nivel de estimativa de valores, inteligencia y cultura de la persona con quien trata. Precisamente, la torpeza social del hombre psíquicamente rústico y los dislates que comete en la vida de relación consiste en la falta de flexibilidad actitudinal que lo lleva a tratar y responder a los demás de manera rígida y homogénea. Para ello se necesita poseer riqueza psíquica y experiencia de la vida. Alguna vez el maestro Pedro Laín Entralgo, filósofo e historiador de la medicina, me dijo:

Aquí en España decimos que el hombre debe ser de una sola pieza, pues a mí me parece que un hombre de una sola pieza es un imbécil; un hombre debe ser de muchas y variadas piezas con tal de que estén muy bien concertadas.

A lo cual le repuse:

Estoy de acuerdo, un hombre debe usar sus múltiples y variadas piezas psíquicas según los requerimientos de la situación y es bueno que estén concerta- 
das pero si a veces no lo están quizá pueda ser mejor, ipues del chillido del contraste y fricción entre ellas pueden saltar las chispas del genio!

El psicólogo ha de estar abierto a todas las posibilidades motivacionales de la conducta humana y abandonar la visión tubular a que lo reduce el prejuicio de escuela. Y quizá si hubiera que buscar una motivación fundamental habría que encontrarla en la autorrealización de sí mismo, como a su manera lo han observado el neurobiólogo genial Kurt Goldstein en el campo de la biopsicología del sistema nervioso humano y Abraham Maslow, en su psicología humanística. Al servicio de la autorrealización, sea para la plenitud o la frustración del ser propio, están todas las demás motivaciones, los contrastes, los sufrimientos, las derrotas o los placeres de la vida. Como dice el gran maestro Honorio Delgado: "No es posible aceptar como instinto fundamental ninguno de los que por definición son tendencias parciales o instrumentales: llámense instinto de conservación, egoísmo, libido sexual, voluntad de dominio, agresividad o instinto de muerte". Y culminando la abarcativa clasificación de la variedad enorme de los instintos humanos realizada por Alexander Pfänder, Honorio Delgado concluye con esta afirmación que tiene la verdad, la grandeza y lo sentencioso de un apotegma: "La cifra del instinto fundamental de cada persona sería: Quiero llegar a ser lo que ya soy en germen" (Delgado, 1938).
Y aquí encontramos otro de los rasgos del perfil psicológico del hombre: una máquina puede descomponerse, un vegetal puede agostarse y así marchitarse, un animal puede enfermarse y morir, solamente el hombre como persona puede frustrar su existencia, falsificar su ser, despersonalizarse. Es entonces que podemos presenciar el triste y único cuadro humano: sólo el hombre puede sufrir la terrible añoranza de no haber llegado a ser lo que podría haber sido y tener entonces una conciencia más o menos lúcida, más o menos anestesiada y evasiva de la profundidad de su ser no realizado. Creo que aquí está el problema fundamental de los hombres y no, como suele creerse, en los problemas sexuales, económicos, sociales, de comunicación, etc., que tanto se han magnificado como básicos y que siendo fragmentarios y colaterales pueden ser solamente síntoma o expresión simbólica del básico problema existencial del cumplimiento o fracaso del propio ser sí mismo. En la psicología del hombre superior se da el destino como una cierta configuración del modo de ser y manera de vivir que enriquece la existencia humana en altura de valores, en complejidad de psiquismo, en sutileza de pensamiento y hondura espiritual de la persona. En el hombre mediocre tenemos un psiquismo rudimentario si no embrionario, poco vivo en imaginación, no-activo en inteligencia ni dinámico en memoria formalizadora; un psiquismo poco inte- 
grado y teledirectivo, sin metas nítidas, un psiquismo que propiamente se podría observar como indiferenciado. Esto hace al hombre mediocre y destino, sin rumbo. Esto es lo común de los mortales, es lo que los franceses llaman l'homme moyen sensuel. El hombre, cada vez más influido por la exterioridad, por la moda, por el contagio emocional e ideológico colectivo llega a ser lo que es, en función del vaivén del oleaje y el empuje del viento. Pero el hombre con destino es uno en quien ninguna época, ningún acontecimiento, ningún tiempo ni ningún poder podrá destruir, hacer añicos, la "acuñada forma que viviendo se desarrolla y evoluciona" (Goethe). El hombre común, por el contrario, es amorfo y pasivo a los factores externos. Y es lo que predomina por la influencia empobrecedora, avasallante del medio externo. No es extraño que las tendencias doctrinarias y metodológicas de la psicología actual sean adecuadas al tipo de hombre de la época, es decir, sean doctrinas y escuelas que dan el predominio exclusivo a la explicación "ambientalista" del comportamiento, y algunas hasta hayan suprimido la vida psíquica interna del campo de la psicología. Parecería que el animal profundo del mundo urbano científico-técnico de nuestra época estuviese perdiendo hondura psíquica y espiritual, alineándose en la chatura de la nivelación por lo bajo, por lo superficial y externalista, sin interioridad.
En la segunda mitad del siglo XVI, Michel de Montaigne (1941), en sus famosos Ensayos escribía: "La plus grande chose du monde c'est de savoir être a soy" y que yo traduzco abiertamente en la plenitud de su ambigua significación: "La cosa más grande del mundo es saber ser sí mismo y saber estar consigo mismo", pues la cosa más insignificante existencialmente del mundo, la más mezquina situación personal, la suprema miseria del psiquismo, es no saber ser uno mismo y alienarse en cualquier forma de caricatura psicoespiritual y conductual imitativa de otro, sea persona o moda o corriente social o ideológica, es decir, esnobismo; y no saber estar solo, consigo mismo, sintiéndose aburrido o amargado. Es que, en verdad, la autofalsificación y la amargura constituyen el más profundo fracaso existencial a causa de un psiquismo de escaso vuelo espiritual. Quizá la máxima autorrealización sea lograr llegar a ser sí mismo con lo mejor de sí mismo. Y la suprema, la divinización del espiritual avanzado. Y ello en honda humildad.

\section{Carácter multimotivacional del PSIQUISMO HUMANO}

En suma, es preciso aceptar el carácter contradictorio y multimotivacional de la conducta humana. $\mathrm{Y}$ al aceptar la variedad de motivaciones y el contrapunto estructural de su corriente dinámica, no solamente nos damos cuenta de la dimensión de profundidad del 
animal humano, sino también de la complejidad del entrelazarse de las motivaciones muchas veces ocultas e inadvertidas por el propio sujeto en que ocurren. Ante esta complejidad y profundidad resulta superficial y simplista pensar a la manera de los propugnadores y secuaces de escuelas un instinto fundamental basado en generalizar una tendencia parcial totalizadora. Sin pretender abarcar todas las motivaciones que encienden el psiquismo del animal humano, podemos considerar un cuadro descriptivo de las principales:

La motivación hedónica el placer (hedonè), la búsqueda de delicia constituye un acicate poderoso. Claro está que el placer físico, que va desde el simple bienestar corporal hasta el paroxístico orgasmo sexual, no es privativo del animal humano. Incluso el animal adiestrado puede llegar a cierto refinamiento y exclusivismo de la vivencia del placer.

En el hombre el placer puede tener una significación meramente superficial o marginal, episódica, o ser un sistemático recurso escapista que eclipsa insuficiencias, problemas o dolores y preocupaciones más centrales y radicales. El placer puede ser algo profundamente significativo: el placer ligado a la plenitud de realización de sí mismo (felicidad) y que florece como vivencia y expresión de plenitud y completamiento del propio ser en mejores y más altos niveles de humanización, sea en la beatitud del éxtasis místico sea como placer erótico en el abrazo de amor que lo hace cualitativamente más intenso y significativo.

$Y$ en esto se encuentra una característica del psiquismo humano: el carácter que tienen sus vivencias como niveles de humanización o de niveles de deshumanización. De un perro no puede decirse que está más perrificado o menos perrificado, o desperrificado o perrificándose cada vez más; o de un león que unos actos sean más leonizados que otros, o que se haya desleonizado. En cambio del hombre sí tiene sentido decir que se es más hombre o menos hombre. Es así que el placer, por ejemplo, se puede insertar más o menos en un más alto nivel de humanización. El placer puede tener grados según el nivel de humanización, agrado sensorial, suavidad táctil, placer gustativo en sus diversos matices de delicia como en el vino, etc.; placer sensual, estado de felicidad, júbilo, estado gozoso, beatitud. Son los niveles de humanización del placer según su dación periférica y superficial o central y profunda, desde el punto de vista psicoespiritual.

Motivación filocrática es el impulso a dominar que puede ser muy intenso en algunos individuos que tienen la pasión de mandar. La voluntad de poder puede a veces realizarse en las formas más sutiles, incluso a través del sometimiento. Como toda motivación vital el impulso de someter lo compartimos con los animales, especialmente con los primates superiores. Los etólogos han estudiado 
lo que llaman hacken ordnung, observando a las aves que se comportan en el recinto territorial en una escala de agresividad sucesiva que empieza con el picotazo del más fuerte y termina con el picotazo que recibe el más débil e indefenso. Parecería no cosa de aves sino una suerte de fábula esopiana aplicable a lo que ocurre entre el personal de la organización administrativa de los centros de trabajo en las ciudades de los hombres. La cadena del orden del picotazo parece imperar en las oficinas, talleres y en toda organización humana usualmente mediana y desespiritualizada. En esa cadena se frustra la libertad y la dignidad de la persona. Romper esa cadena es tarea de una psicología pneumoanalítica (pneuma espíritu).

La motivación social tiene gradaciones y matices, desde el gregarismo que nos asimila al rebaño, la angustiosa inquietud de no poder estar solo que tiene cierta gente, hasta las más diferenciadas motivaciones sociales del amor y de la amistad. Hay una fina y muy diferenciada motivación social que toca fibras muy finas de la existencia humana personalizada: el tener un para alguien y el ser con otro. Se trata de profundas motivaciones del ser humano como persona y que si se frustran caemos en la aridez y en la desolación. Psicológicamente las describimos como motivaciones sociales diferenciadas y personales, pues nuestra vida se vivifica y se enriquece sabiendo que hay un alguien para quien uno vive, y que otorga sentido a nuestra vida; o que al compartir con otra persona la vida se rompe la soledad y viene un diálogo existencial que le da un sentido de amor y de amistad, de solidaridad, de compañía a nuestro existir. La profundidad del animal humano exige una psicología que ahonde en el sentido que obra la existencia en el ser para otro y en el ser con otro, sentido que modifica totalmente sea por realización o por frustración el carácter, los sentimientos, las conductas, las actitudes, los modos de ser y las maneras de vivir, la naturaleza del psiquismo, involucradas en esas dimensiones de la relación social rigurosamente personal. Es que la motivación social arraiga en uno de los existenciales que Martin Heidegger considera en su Analítica existencial: "mit-Sein", "Ser-con" (Heidegger, 1957).

La motivación espiritual pneumotéli$c a$ es la necesidad de espiritualidad. Se trata de la realización de ciertos valores que en lo superior sublimizan la existencia humana y en lo supremo la divinizan haciéndola, precisamente, más humana, más genuinamente humana. Me refiero a valores elevados: la bondad y la belleza, la verdad y la justicia, las conductas responsables y los comportamientos eficaces y cuidadosos, las actitudes y los sentimientos que revelan estilo y grandeza, ternura que es consideración y dulzura, generosidad y desprendimiento, elegancia y tacto, 
imaginación y gracia, delicadeza y pulcritud, todo ello es espiritualización de la vida humana. Sin esto, nuestras supremas exigencias psicoespirituales de elevación de nivel y de calidad de nuestra existencia se verían frustradas y arrastraríamos una existencia indigna del hombre, y muy por debajo y deformada de la belleza del animal. Gracias a la espiritualización el hombre se realiza en un segundo nivel de vida animal, la de la profundidad del psiquismo noetizado (insuflado de pensamiento configurador, abstracto y simbólico). Y en la plenitud de la espiritualización el animal humano, el primate hominizado, hasta puede alcanzar un tercer nivel de belleza de vida como es el caso de la suprema espiritualidad que es la vida del santo liberado en vida ("jivamukti”), y cuya motivación radical es lo que Agustín escribe: "attingere alicuantulum mente Deum, magna beatitudo est" ("tocar un poquitito con la mente a Dios, es grande felicidad") y que fundamenta lo que llamamos "amor fuerte".

\section{Psicodinamia De las Motivaciones}

Las motivaciones psicológicas tienen el carácter de fuerzas direccionales y con sentido. Son verdaderos vectores psíquicos. Las motivaciones, por ende, dinamizan el psiquismo y movilizan la percepción y la acción. En lo anterior hemos puesto énfasis en el sentido de las motivaciones según los valores y objetos (depositarios de valores) a los cuales se dirigen. El factor dinámico fundamental es indudablemente la atracción que sobre el sujeto ejercen los valores. Y de eso hemos tratado. Ahora más bien se trata de enfatizar la complicación, relación y contradicción de las fuerzas dinámicas. Es lo que se puede llamar la psicodinamia del psiquismo o para usar otra expresión de Honorio Delgado, la fuerza "dinamogénica", su carácter generador del dinamismo psíquico y la manera como las motivaciones se expresan, se combinan o como se contrastan. En suma, se trata del dinamismo de lo que suelen llamarse instintos, acicates, pulsiones, impulsos instintivo-afectivos que constituyen el caudal dinámico del psiquismo. No se puede solamente enfatizar o exclusivizar en el psiquismo el nivel noético, es decir del pensamiento cognitivo. El nivel profundo, pático (pathos, afección, afectividad) es el que ahora vamos a tratar. Es que al hablar de motivaciones e instintos nos referimos indistintamente a los deseos, temores, inclinaciones, rechazos, pasiones que se encienden en los hombres y los encienden en sus relaciones personales y sociales. Es, pues, la vida instintivo-afectiva.

Estas fuerzas de los instintos son la sustancia de que está hecha la vida animal. Es el estrato primario y primitivo en la evolución filogenética y, más interesante aún, en la evolución ontogenética del psiquismo. Corresponde a los estratos paleoencefálicos, desde el 
bulbo-raquídeo, la llamada sustancia reticular, la zona límbica, el tálamo e hipotálamo, en fin, las estructuras vinculadas a la vida vegetativa, al sueño y la vigilia, a las emociones, a la agresividad y al sexo.

Decimos que los instintos son la sustancia de que está hecha la vida. Pero en el hombre se dan dos rasgos diferenciales a nuestro juicio respecto de la vida animal, en la cual el hombre forma parte como animal profundo y como tal a su vez se distingue: lo primero es la índole de los instintos cuya gama es más amplia que la del animal, lo cual se ha tratado en la sección anterior; el segundo es la manera como los instintos o motivaciones conductuales se estructuran en el hombre en constelaciones complejas. Es lo que tratamos en esta sección. La pregunta aquí es: ¿Cuáles son las formas específicas que, en el hombre, tienen las motivaciones de entrelazarse, de combinarse, de contrastarse o de refrenarse? Esto es: ¿Cuál es la psicodinamia humana de las motivaciones del psiquismo?

Freud creyó encontrar lo fundamental de la psicodinamia en el conflicto entre el principio del placer radicado en el "ello", suerte de fondo turbulento, hervidero anónimo, impersonal, de impulsos alojados en el estrato más profundo, el subconsciente, y el principio de realidad, super-yo, cultura que contradice al ello y constriñe la libre realización de la "libido" o impulso erótico, creándose así contenidos latentes, re- primidos de carácter subconsciente y que actúan mediante efectos indirectos en el nivel consciente. El yo, ubicado en esta estratificación, entre el ello que lo empuja y el super-yo que lo comprime, se encuentra trajinado en este oleaje contrapuesto.

Freud concibió este dinamismo de contradicción y represión en términos mecánicos, consecuente con la imagen de "aparato psíquico", la cual le sirvió para describir el psiquismo: la energía libidinosa del "ello" reprimida por la censura impuesta por el super-ego, queda comprimida y comprimiendo al yo, que queda como atrapado entre dos tendencias conflictivas y contradictorias, el "hervidero" del "ello" y la censura del "super-ego", la gana de satisfacer el principio del placer y la inhibición que causa el principio de realidad, identificado como la cultura concebida en una función esencialmente represiva de lo natural. El principio de realidad (que a mi juicio es la realidad autoritaria y represiva del puritanismo social) que se opone al principio de placer, produce una fuerte tensión acumulativa en el angustiado yo, el cual atrapado entre estas dos fuerzas ya no puede ahogar esa energía erótica comprimida. La libido erótica frustrada, sin embargo, ya no puede ser sofocada, ser ahogada, prisionera, se libera indirectamente, sale afuera en forma de trabajo anestesiante y compulsivo, o en forma de "neurosis" (término inventado por Freud), o de ensueños, de "actos falli- 
dos", y por último en forma que llamó "sublimación" tomando, como hemos dicho anteriormente, esta palabra metafórica de Nietzsche, quien la usó para explicar en "la química de los sentimientos" el origen y carácter vil de los sentimientos nobles y sublimes. La vileza que está en el antecedente de la sublimación freudiana es el eros sexual. En Nietzsche la genealogía de las sublimidades de la moral cristiana, tales como "perdón", "amar a los enemigos", "no vengarse", tienen un origen ruin del cual deriva el resentimiento, el odio, la impotencia. La sublimación nietzscheana instaura o descubre un interesante transformismo psicológico: lo ruin de la cobardía, de la impotencia y del resentimiento tienen el poder creador de valores morales. Nietzsche inauguró la psicología de la sospecha y del desenmascaramiento. Lo cual significó un avance en el saber psicológico, pero, al mismo tiempo, significó un retroceso y una deformación al servicio de una psicología reductiva y de nivelación, una psicología iconoclasta que no reconoce la experiencia psicoespiritual genuina de la experiencia de los valores superiores. El avance de las multitudes anónimas y resentidas, el aumento de la psicología de masas y de población mediocre, llena de ambiciones frustradas, favorecieron inmensamente la acogida de la psicología iconoclástica de Nietzsche y Freud como un medio de aliviar la amargura de no poder llegar a la grandeza. El aumento de los crímenes en el sentido del magnicidio que ocurre en el confuso anonimato multitudinario de las crecientes megalópolis tiene su explicación en estos tortuosos caminos y enlaces de la psicodinamia de la frustración y del resentimiento.

Es extraordinariamente interesante esta psicodinamia inaugurada por Nietzsche y expuesta con detalle $y$ puesta de moda por Freud. La estructura esquemática del aparato psíquico, que Julian Jaynes en su extraordinario libro El origen de la conciencia en la ruptura de la mente bicameral (1987), comparó acertada y humorísticamente a las locomotoras de vapor decimonónicas, es indudablemente mecánica. Puede valer como descripción metafórica adecuada para muchos casos individuales y colectivos inmersos en la concepción del mundo prevaleciente en el puritanismo, con sus fobias sexuales y pudores vergonzosos relacionados con las funciones fisiológicas. Es la vergüenza de lo animal llevada a extremos de considerar los órganos corpóreos como monstruosidades repugnantes a disimularse con toda clase de máscaras y maquillajes. La concepción del mundo puritana de la que Freud se hace eco es aquella que influyó en él, quizá sin advertirlo muy lúcidamente, para elaborar una metapsicología y una antropología en la cual la cultura tiene un papel de superestructura represiva. La cultura como enemiga de la vida y del placer erótico. El 
esquema freudiano del "malestar de la cultura" no vale como esquema antropológico. Solamente tiene cierto valor epocal y circunscrito a ciertos casos, no valor universal. Tampoco la metáfora mecanicista de la función represiva y antagónica del principio de realidad y del superego respecto de la vida erótica y de la libertad de desarrollar el principio del placer. La concepción psicoanalítica de Freud no tiene más valor y aplicación que en función de las circunstancias particulares en que fue concebida y podía tener alguna aplicación. Basta recordar los desarrollos y las formas que hemos descrito del "amor cortés" en la Edad Media, para darse cuenta de que la cultura, la poesía, la música y los valores vigentes en ese círculo de vida cortesano y trovadoresco del siglo XII, lejos de reprimir el eros, abrió caminos de vuelo y delicia para lograr la apertura elegante, dulce y sublime a la vida sexual. Y el factor represivo del matrimonio convencional más bien favorece al florecimiento de la poesía y de la música como caminos secretos, eficaces y bellos para la salida sublime, no sublimificada, del impulso erótico genuinamente realizado en la unión mutuamente gratificante de la pareja del poeta y la princesa. En el "amor cortés" se muestra en toda su encantadora evidencia que la sublimación de la vida erótica no sustituye al objeto del impulso -el cual es el coito, el abrazo sexual de los amantes- sino que le da formas y medios encantadores para realizarse. Lo sublime no es el disfraz de lo bajo y vil como los 'puritanos' decimonónicos Nietzsche y Freud pretendían. La sublimación, fenómeno de alcanzar y de realizar niveles de experiencia y de forma superiores en calidad y belleza, no consiste en transvestir lo innoble con formas nobles, eludiendo la satisfacción del impulso erótico, el cual no tiene nada de vil ni de innoble, en el objeto mismo del impulso utilizando una sustitución aparentemente superior que lo reemplaza y que lo representa simbólicamente. El fenómeno de la sublimificación existe y eso es lo que vieron Nietzsche y Freud, pero lo que consideramos como sublimación es distinto. Siempre la sublimación ha tenido un sentido genuino hasta que la psicología iconoclasta del desenmascaramiento y de la sospecha, la psicología calumniosa que quiere ver lo abyecto en la grandeza, envenenó la palabra sublimación. Por eso prefiero utilizar la palabra "sublimificación" para referirme al hecho que ha ocurrido a causa de la represión sexual del puritanismo y la influencia tóxica de la proliferación de las multitudes de fracasados y mediocres que calumnian la grandeza que no alcanzan. Nietzsche, sin quererlo, quién lo diría, ha sido el ideólogo de los fracasados suministrando una interpretación de la genealogía de toda grandeza; Freud, transplantando la psicodinamia sexual, la metáfora de la sublimación, se convirtió quizá en el 
ideólogo de los reprimidos sexuales a causa de la moralidad puritana que es sexofóbica. De allí el éxito de ambos en el siglo XX.

Freud agregó a la libido o pulsión erótico-placentera un nuevo instinto con el carácter de básico o fundamental del psiquismo humano: tánatos, el instinto de muerte. Se trata del principio tanático que está en la base de la agresión y de los impulsos destructivos. Hay en este instinto cierta asociación que hace Freud con el nirvana búdico, como un deseo de extinción, una voluptuosidad de disolución, de vuelta al no ser. El sistema de pensamiento, la práctica y la experiencia budista de la iluminación y el sentido búdico (despertar, buddhi, el despierto, Buddho) del nirvana (apagamiento del deseo codicioso insaciable de placer y de poder, purificación de todas las intoxicaciones psíquicas que enturbian la claridad de la mente e impiden el conocimiento) no tienen nada que ver con esta doctrina freudiana que, con su carácter biologista de tedio, cansancio, desgano de vivir y voluntad de suicidio y obsesión de la muerte, se aleja del resplandor luminoso, vitalmente activo y enérgico, amoroso y feliz, bienaventurado del budista que ha logrado el término de su liberación, precisamente libre y despierto de lo que oprime y atormenta al común de los hombres dormidos agitados por los ensueños y pesadillas de la vida. Este emparentar el motivo genuinamente sublime y es- piritual con una oculta paternidad de un móvil subrepticio, el sublime nirvana búdico que lleva a la vida superior y el móvil tanático freudiano que lleva al suicidio, es típicamente aceptado y festejado en ambientes que necesitan rebajar la altura del psiquismo superior.

Me parece urgente y esencial replantear el tema de la psicodinamia de las motivaciones sin el lecho de Procusto de imponer un esquema doctrinario de escuela, como es el caso de la "sublimación" nietzscheano-freudiana, que en realidad sólo viene a ser un caso particular, no universal, de carácter epocal y no esencial del psiquismo del animal humano. Esta sublimación entraría como una de las formas de confluir las motivaciones que en mi observación son las siguientes: a) la represión; b) la contención; c) la sublimificación (que viene a ser la correcta formulación de la "sublimación" nietzscheano-freudiana); d) la "espiritualización" o "genuina o auténtica sublimación". Creo que hay que hacer estas distinciones en la forma de darse la psicodinamia porque suele confundirse contención con represión (y peor aún con "represión neurótica" y también "sublimificación" de los instintos, tendencias o motivaciones con la "espiritualización" de la experiencia psíquica y conducta global (perceptivo-intelectivo-afectivo-activa), vinculándola necesaria e indebidamente con los fenómenos de "represión". 


\section{PSICODINAMIA DE LA REPRESIÓN}

La represión de los instintos y tendencias constituye una inhibición traumática de las motivaciones y actividades correspondientes. Suele ser por un conflicto entre deseo y temor. Es decir, se teme lo que se desea y se paraliza el libre flujo de las acciones correspondientes a la motivación. El móvil no mueve. $Y$ el deseo se vuelve temor. Freud supone en la psicodinamia del psiquismo necesariamente el conflicto. Ya hemos visto el conflicto entre el superego, tomado como principio de realidad (proyección de la imagen paterna, código moral represivo, puritanismo de Weltanschauung) se contrapone represivamente a la "libido", el principio de placer, el hervidero que surge de las profundidades del "ello". Este conflicto lleva a la inhibición represiva, traumática de las motivaciones espontáneas. Freud, influido por el puritanismo vigente, piensa que el superego es principio de realidad. Pero, como lo ha hecho notar Marcuse, si se trata de una realidad liberada, abierta, sin opresión socioeconómica, la represión no tiene por qué darse ni por qué canalizarse la energía reprimida en trabajo alienante y opresivo. El trabajo puede llegar a ser una forma libre y placentera de autorrealización. El trabajo como actividad gratificadora y creadora. Es la conciliación, la confluencia entre el deber, motivación espiritual, y el placer, móvil sensual. En la represión sí hay un conflicto, como estamos viendo, pero no toda relación entre motivaciones es necesariamente conflictiva, a veces puede ser una relación confluyente, como puede verse en lo que llamamos espiritualización o sublimación genuina.

La represión, pues, está en el conflicto entre motivaciones contrapuestas y no sólo se presenta en el hombre, sino también en los animales, pues tiene una base y un carácter biopsíquico, si se trata de la represión vital. Podemos ponernos en otro caso inverso, en que, en lo humano, el conflicto y la represión no suponen, necesariamente, la inhibición de los instintos vitales. Tenemos los casos de la ninfomanía, la agresividad desatada, los impulsos irresistibles efectuados, la satiriasis, la bulimia, que pueden significar formas de escapismo a la frustración de la realización de las tendencias espirituales más elevadas, reprimidas, por temor, por perfeccionismo frustrado y exigente, por excesiva y obsesiva escrupulosidad, sentimiento paralizante de indignidad, el fracaso de la existencia, el desencanto de la falla o mediocridad de las más altas aspiraciones y aptitudes. Es decir, la represión de las tendencias sublimes y de las inclinaciones más altas y nobles puede motivar la desilusión de sí mismo, el desencanto frente a las mejores expectativas y producir el desencadenamiento desordenado de los impulsos viles o móviles "bajos", llevando a lo que llamo 'experienciomanía', al desenfreno hedonístico, a todas las formas de la evasión o aturdimiento para, 
a su vez, escapar al horror del vacío espiritual de base. Esta grave represión de la motivación espiritual entraña fracaso existencial que busca consuelo no sólo en la desinhibición impulsivo-biológica, sino en la toxicomanía y en la otra forma de drogadicción intelectual que es pretender la justificación del fracaso de la espiritualidad construyendo o adoptando una concepción del mundo nihilista, cínica y peyorativa de la vida. Tenemos que frente a la represión vital, inhibición de la vida instintivoafectiva, que es lo que frecuentemente se piensa, tenemos también lo que llamo la represión espiritual, que requiere, a mi juicio, un estudio más detallado y más atención por parte de los psicólogos. El puritanismo y la influencia de Freud ha creado esta atención, lo que puede llamarse "represión vital", es decir, lo que Philipp Lersch llama lo “endotímico” (Lersch, 1968).

\section{Psicodinamia de LA CONTENCIÓN}

La contención consiste en un proceso de carácter volitivo-espiritual por el cual se incorpora la fuerza propulsora del impulso dentro de las motivaciones superiores, regulando su acción efectora, ya sea posponiendo su descarga o realización, modulándolo o simplemente manteniéndolo latente $\mathrm{y}$, en caso necesario, suspendiéndolo o suprimiéndolo conscientemente en uso de la capacidad estimativa de los valores involucrados.
Se trata de un fenómeno consciente, y hasta reflexivo, inscrito en el ser personal del sujeto del psiquismo. En cambio, la represión y las inhibiciones fóbicas constituyen dinamismos, mayormente de origen y presencia subconsciente, instalados y enclavados en el psiquismo humano, que funcionan en forma relativamente autónoma del yo e incluso se imponen al yo causando trastornos. La represión constituye, con relación al yo y a la totalidad del psiquismo, una suerte de Estado dentro de otro Estado, un verdadero enclave psicológico. El papel, en este caso del método psicoanalítico, ha sido el de tratar de liberar el psiquismo de esta subyugación enajenante, tratando de acrecentar el dominio del yo en este territorio ocupado por fuerzas subversivas. Esto es en esencia neurósico cuando el enclave de la represión funciona como un quiste psicológico. En todo caso, es interesante preguntarse si el enquistamiento del factor causante del síntoma neurósico no sea precisamente un medio de defensa de las fuerzas sanas del psiquismo y del cerebro. Y, entonces, lo inconveniente es remover el quiste con la inoportuna anamnesis psicoanalítica.

Por el contrario, en la contención el yo subordina los impulsos, los maneja, mantiene su señorío y ejerce su libertad. En la represión en que se produce inhibición neurótica, el yo más bien sufre menoscabo de su libertad. Esto ocurre en la represión vital, pero el recorte 
de la libertad y la subyugación del dominio o señorío del yo ocurre también con lo que llamo represión espiritual, y es cuando el yo accede, o cede, contra sus motivaciones superiores, a las exigencias de las pulsiones vitales primarias. Debe anotarse que la permisividad ambiental y esta esclavitud respecto de los impulsos primarios se suele gratificar en esta época -falsificando la auténtica psicodinamia que discierne entre los fenómenos de la represión respecto del fenómeno más elaborado, y de un psiquismo sano y maduro, que es el de la contencióncon la muy mal empleada palabra "liberación". La contención está orientada, como veremos, a la espiritualización de los impulsos.

El psicoanalista consecuente quizás podrá decir, en algunos casos con razón, no en todos, que lo que llamo contención -y al hablar así lo que estoy haciendo no es sino una "racionalización de la represión", lo cual en muchos casos puede ser cierto, pero entonces ya no se trata de contención sino efectivamente de una "racionalización de la represión"-. Pero desconocer la realidad y legitimidad de la psicodinamia de la contención volitivo-espiritual como fenómeno genuino y tratarlo de ver como máscara de procesos subconscientes encubiertos, es caer en la sospecha y en la manía del desenmascaramiento como método psicológico exclusivo. Para mí sería una deformación del valioso método psicológico inaugurado por
Nietzsche, como hemos dicho, pero que usado por los seguidores sectarios del freudismo no expresa sino la hipertrofia morbosa de los resentidos contra toda forma de superioridad, excelencia y sublimidad de la existencia diferenciada. Contención: psicodinamia de sublimidad.

\section{Psicodinamia de la}

\section{SUBLIMIFICACIÓN}

Me he referido anteriormente varias veces a la "sublimificación", su origen y aplicaciones, y su diferencia con la genuina sublimación. En el psicoanálisis la sublimificación o sublimación freudiana constituye una salida de la carga libidinosa reprimida por la cual el móvil inferior o impulso erótico frustrado se transmuta aparentemente, se transviste en motivos superiores que no resultan ser sino disfraz o máscara. Esto es, en síntesis, lo que nos quieren decir Nietzsche, el inventor del término y concepto psicológico de sublimación, y Freud, en su restricción al fenómeno sexual cuando tratan de este fenómeno psicodinámico. Es claro que el descubrimiento de esta psicodinamia es una importante revelación en el conocimiento del psiquismo humano. Tal psicodinamia, que Nietzsche llama "química de los sentimientos y de las ideas" y por la cual un sentimiento abyecto se transforma y se disfraza en idea sublime, existe. Más aún, esto nos da la medida de la complejidad del hombre y de la profundidad del animal humano. 
Que un impulso que no logra su objeto se transmute, embelleciéndose para evitar la ansiedad frente a las exigencias de una instancia superior normativa y obligante, de manera que sortea el obstáculo para satisfacerse de manera indirecta en objeto distinto y superior al del impulso, creado especialmente para este sinuoso rodeo, es indudablemente muy interesante, y hace del hombre un animal también interesante. Y tiene, sin lugar a dudas, el sentido de un recurso defensivo frente a la ansiedad.

En los animales se dan también recursos defensivos cuando la tensión llega al máximo, pero son más simples y directos. $\mathrm{Y}$ es que los animales no metaforizan la vida como el hombre. Cuando la pelea de gallos llega a su climax (y mientras que el hombre no haya puesto una navaja amarrada en una pata) uno de los gallos suspende su actitud y comportamiento agresivos y pasa a un inofensivo ponerse a picar el suelo como si estuviese comiendo grano. Es decir, suspende la lucha mostrando una conducta pacífica y desconectada de toda agresividad. Entonces, el contendor también suspende la agresividad y por ende la lucha termina.

Hay una cierta analogía con la "sublimificación" nietzscheano-freudiana: desplazamiento del impulso y las actividades "sustitutorias" o, si se quiere, "sublimes", que calman la excitación y descargan el impulso con acciones y objeto distintos de los adecuados y pro- pios que las produjeron. La "ritualización" del impulso agresivo podría ser un buen ejemplo de "sublimificación" por "sustitución". Sin embargo, creo que los etólogos han magnificado el lenguaje. Hay un mecanismo claro de "sustitución", que es el mismo recurso utilizado en la "sublimación" nietzscheano-freudiana, pero en los animales faltan dos cosas que sí se dan claramente en el animal humano: a) no hay una escala de valores que permita hablar de móviles inferiores que se subliman en motivos superiores o aparentemente sublimes; b) el animal no humano es llano y directo, no intermedia su acción mediante "símbolos". Por ello, el animal tiene un psiquismo superficial, no es profundo, y por ello no puede ser hipócrita.

En cambio el hombre sí usa símbolos y disfraza sus móviles, sea consciente como inconscientemente, o mejor, sea advirtiéndolo o no (para no hablar en términos psicoanalíticos). Freud en la "sublimación" sólo se refirió al disfraz del impulso erótico reprimido. Sin embargo, la "sublimificación" puede referirse a otros impulsos, voluntad de poder, codicia de posesión, sea de dinero, cargos, beneficios, etc. Ahora sólo quiero hacer la diferencia entre sublimación y sublimificación respecto de la voluntad de poder. El resentido social, sordamente afectado por la privación de bienes que ambiciona, se siente desposeído injustamente. El resentido social no suele, cuando es inte- 
ligente y tiene información superior y educación política, gritar a voz en cuello su envidia, su ambición. La ambición de status y la amargura de su desposesión envidiosa, es decir, los impulsos vitales o móviles reales como la voluntad de poder y la codicia de posesión, se disfrazan entonces de voluntad de servicio y entrega filantrópica. Es decir, los móviles se sofistican, se espiritualizan, se convierten en sublimes motivos de acción desinteresada, en actividad social benéfica y en política. Nuestro envidioso ilustrado puede convertirse hasta en luchador social, violento y peligroso. Esta es la psicodinamia profunda, oscura y hasta quizá inadvertida por el propio sujeto, quien se siente portador de una misión y que, sin embargo, es una reivindicación de sus necesidades, frustraciones y carencias. La piedra de toque llegará algún día cuando venga la tentación del poder y de la riqueza ya no como bienes instrumentales sino como alienantes bienes absolutos. Aquí, en este caso, sí opera la interpretación desenmascaradora, pues hay un verdadero rostro oculto: codicia, voluptuosidad de poder, ambición de status, envidia; y una máscara que lo encubre: voluntad de servicio, filantropía, justicia social. Es un perfecto caso de "sublimificación", es decir, de hacer sublime, entrega política de servicio, lo que no es sublime, codicia de status.

Pero no se puede universalizar, como pretendería Nietzsche, para las motiva- ciones humanas sublimes ni para toda expresión sublime de la vida erótica. Puede darse el luchador social auténtico y el político espiritualizado. En ambos casos la voluntad de poder no es un fin en sí mismo sino una voluntad que entiende el poder como instrumento de servicio. En ambos casos se concibe la política como misión y profesión que obliga y abre el camino a realizar valores espirituales como justicia, solidaridad, bien común, orden racional y democrático, autoridad ética, respeto a las instituciones y a los derechos humanos, apoyo y promoción para la realización humana plena de la persona humana. Es entonces del caso de la sublimación elevar el impulso primario al nivel alto de la motivación espiritual.

\section{Psicodinamia de la ESPIRITUALIZACIÓN O GENUINA SUBLIMACIÓN}

Se trata de la espiritualización del impulso vital como un medio elaborado esencialmente humano de realizar el impulso en su objeto propio sin sustitución. El impulso no es reprimido sino realizado y satisfecho, pero no de manera cruda sino a través de modos y formas espiritualmente superiores y culturalmente finas, elegantes, encantadoras. El impulso erótico al subsumirse en el modo y nivel de la espiritualidad se enriquece de sentido y de intensidad de vivencia. Y para esta espiritualización el impulso vital tiene que suspender su inmediatez y carácter 
urgente y entrar en nuevas formas que demandan postergación y espera. En las exigencias de forma que hemos visto en el amor cortés vemos una realización típicamente demostrativa de lo que entendemos por espiritualización del impulso vital. La cruda vitalidad al espiritualizarse adopta un tempo y una forma superior que la hace discurrir en nuevos senderos de actividad refinada y que llevan a la plena y auténtica satisfacción, es decir en el objeto propio y no sustituido ni transmutado en símbolo o convertido en valores espirituales o morales sublimificantes. El impulso vital se despliega despertando valores de forma, de belleza, de encanto en su paso al encuentro de su fin propio, en el cual se realiza. La espiritualización del impulso vital no trae una sustitución de objeto. En verdad, en la espiritualización ocurre que la cultura interviene en natura, embelleciéndola $\mathrm{y}$ dándole nuevas formas sin cambiar el fondo erótico sino más bien intensificándolo. Tal cosa puede ocurrir en el apetito, cuando su satisfacción no está atada al inmediatismo grosero del tragar. Se espiritualiza el apetito, la gana, el tener hambre, cuando se realiza mediante refinamientos de maneras e instrumentos, platería u oro, cristalería, manteles y candelas. El apetito, como impulso grosero, cuando sólo satisface una necesidad inmediata de hambre, en cambio, cuando es espiritualizado por la cultura o cultivo humano esmerado, no desvía su fin ni éste sustituye sim- bólicamente a la comida con la cual se satisface porque es su objeto natural. Y al adquirir niveles de refinamiento $y$ formas de elegancia y cortesía, niveles de formas más exquisitas, el apetito alimenticio se sublimiza y no por ello cae en la sustitución simbólica de la sublimación nietzscheano-freudiana. El grave error de ésta es haber deformado lo que se llama sublimación y con la deformidad haberla exclusivizado como psicodinamia universal del psiquismo humano (Nietzsche) o como psicodinamia interpretativa de los escapes colaterales y simbólicos de la represión sexual de la libido (Freud). Por eso insisto en llamar "sublimificación" a la psicodinamia que malentiende lo que es un legítimo y genuino proceso de sublimación. Lo cual no impide que en algunos casos la experiencia del sujeto consista en una psicodinamia de artificiosa y sinuosa sublimificación a la manera nietzscheano-freudiana, y en otros casos la vivencia del sujeto consiste en una esplendorosa sublimación del impulso vital por su clara y legítima espiritualización.

La sublimación espiritual auténtica es una realización sursumactiva de un acto vital en un acto espiritual que lo transfigura sin sustituir su naturaleza vital ni su objeto propio. La "sursumactionis" es un concepto medieval bonaventuriano que se refiere a la fuerza y forma elevadoras del psiquismo a un nivel espiritual. En la "sublimificación" lo que hay es una supresión re- 
presiva del impulso y del acto vitales que los lleva a una ritualización sustitutoria de la satisfacción en una representación simbólica, gaseosa, que llaman "sublime", "espiritual" y por ende fantasmal, irreal. En cambio en la sublimación genuina la injerencia de la espiritualidad en la realización del acto vital y en la satisfacción del impulso vital es una forma viva y embellecedora, humanizadora. Es necesario descontaminar de freudismo el fenómeno auténtico que llamamos sublimación genuina. Del mismo modo, hay que penetrar en la vena noble e interesante del fenómeno psicodinámico de la espiritualización del impulso vital y librarla de la sospecha nietzscheana y de la necesidad de desenmascararla, pues no tiene máscara, es lo que es en sí misma y no encubre nada. El impulso natural se desarrolla, crece y se transfigura a través de formas cultas y refinadas que lo diferencian del animal y que viene a constituir la profundidad espiritual del animal humano.

Es el mismo Nietzsche el genial descubridor de lo que mejor llamamos "sublimificación" (en el Aforismo 1 de "Humano, demasiado humano") y que Freud popularizó como salida a la represión del impulso erótico, y nos habla de "espiritualización de la pasión". Nietzsche concibe una elevación de nivel cuando afirma: "Las pasiones transfiguradas, su orden superior, su espiritualización". En una primera mirada pareciera que Nietzsche se refirie- ra al mismo fenómeno de espiritualización del impulso vital que nosotros describimos. Efectivamente, Nietzsche usa "espiritualización de la pasión" y nos dice que la "espiritualización de la sensualidad se llama amor" ("Die Vergeistigung der Sinnlichkeit heisst Liebe" Die Götzen-Dämmerung). Esta afirmación la hace en El crepúsculo de los ídolos, donde precisamente se esmera en desenmascarar todo lo que suena sublime y superior. Entonces aquí tenemos otra forma de desenmascarar la verdadera índole subrepticia de eso que se llama amor: el amor no es, en esta frase de Nietzsche, sino sensualidad sexual disfrazada en formas y maneras que se llaman amor, y que al espiritualizarse esconden su verdadera naturaleza sexual. Lo que está debajo del amor es el deseo sensual. Estamos en la misma tónica de degradar tanto la sensualidad como su disfraz espiritualizado que se llama amor. Es decir, esta espiritualización de la sensualidad que Nietzsche considera que es el amor no es sino otro caso, una manera de señalar la misma psicodinamia de "sublimificación". La fina ironía ligeramente sarcástica que esconde la frase de Nietzsche sobre la sensualidad y el amor en verdad es un caso en el cual el propio Nietzsche incurre en lo que él denunciaba como "antitético de la espiritualización" de la pasión y que es la "diabolización del Eros" (“... diese Verteufelung des Eros" Aurora, Aforismo 76). Por el contrario, nuestro 
ejemplo del "amor cortés" sí es un ejemplo de auténtica psicodinamia de genuina espiritualización. En la sublimación hay un reconocimiento del valor de la sensualidad, en la "sublimificación" no; hay desvalorización de la sensualidad como algo que hipócritamente debe disfrazarse con las maneras "espirituales" del "amor", el limpio "amor", cuando en realidad se trata de la "sucia" sensualidad. Este es el fenómeno que Nietzsche tuvo en cuenta y que se debe al puritanismo decimonónico. Para nosotros la sublimación es un fenómeno psicodinámico que abre el espacio interior de profundidad del animal humano. En cambio la "sublimificación" y, como en seguida veremos, la "pseudoespiritualización" nietzscheana son fenómenos psicodinámicos que en la profundidad del animal humano revelan recursos de hipocresía y disimulo, de enmascaramientos que son precisamente los grandes hallazgos psicológicos de Nietzsche, cuyo error fue generalizarlos para toda psicodinamia de los impulsos y desconocer la sublimación genuina en su actitud difamatoria de escándalo.

Sin embargo, Nietzsche ondula pendularmente entre lo que diríamos "sublimificación" (como en el caso del amor y la sensualidad, donde se encuentra uno con un reduccionismo peyorativo del amor a mera sensualidad) y (aparente) sublimación auténtica, en la que se diferencia el crudo impulso de la pasión y su realización a través de lo que considera una refinada espiritualización. Es el caso, por ejemplo, cuando Nietzsche nos dice:

La victoria de la estupidez de la pasión me parece la más grande victoria que jamás se haya obtenido: es decir, conservar la pasión pero amasarla con la levadura del espíritu, de la finura, de la cautela de modo que ella se convierta en $d e$ licia de la existencia [subrayado de Nietzsche]. En el pasado se quería simplemente aniquilar la pasión a causa de su estupidez y de las malas consecuencias que de ellas se derivaban: pero era una segunda estupidez agregada a la primera. (Cuaderno W II 6.43-44 transcrito en la nota 44, al texto de El crepúsculo de los ídolos. Edición nietzscheana de Giorgio Colli y Mazzino Montinari, vol. VI, tomo 3, pp. 494-495).

Nietzsche considera que la cruda pasión, es decir, el impulso ciego, en bruto de la pasión es estúpida por las complicaciones que acarrea y que, por ello, resulta sagaz no suprimirla sino espiritualizarla. En mi opinión, Nietzsche utiliza espiritualizar en el sentido de transformar el sentimiento en pensamiento, la inmediatez del impulso en cautela, transmutar la materia pasional en lo que llama espíritu, y que viene a ser desprender de la pasión su rudeza elemental y procurarla de formas de realización que eviten tal estupidez dotándola de canales en que la acción sea más perspicaz, más sutil, más repensada, más circunspecta, prudente y cuidadosa ("viel klüger, viel nachdenklicher, viel schönender", Mazzino Montinari traduce "molto più inteligente", "molto più pensosa", "molto più moderata"). 
No se trata de espíritu como nivel sublime de valores, sino de cálculo, astucia, maldad. Y esto se ve con claridad cuando dice "nuestro otro gran triunfo es nuestra espiritualización de la enemistad" (subrayado por Nietzsche). Se trata indudablemente de una pseudoespiritualización, en cuanto no hay un ascenso a formas sublimes, es decir, a la nobleza de los valores superiores, pues para realizar el impulso inamistoso, el odio, se trata de quitarle esa estupidez inmediatista imprudente y directa, dándole canales "espirituales" (vale decir recursos de astucia) a la pasión para que se realice en forma más cauta, refinada, más acorde con lo que llama "delicia de la existencia". Es evidente que Nietzsche se está refiriendo a la transmutación del odio y del resentimiento como pasiones que pertenecen a la vida afectiva. Es así que alude a una psicodinamia que revela la existencia de un fenómeno psicológico inquietante en el animal profundo cuando Nietzsche se refiere a este fenómeno de lo que llama "espiritualización de la enemistad". En realidad se trata de una noetización del nivel de pathos. Se trata de una inquietante elaboración que permite realizarse al odio o la enemistad pero hiriendo astutamente en el momento oportuno, no inmediatamente como exige la pasión sino mediatamente como lo piensa la razón impura. Es decir, la que con el pensamiento pondera las condiciones razonables para actuar con el máximo de eficacia y con el menor riesgo. Se trata del pensamiento al servicio de la pasión para postergarla y hacer que el acto sea más prudente, cuidadoso y eficaz. Es esto indicativo del animal profundo, el hombre, como el animal más peligroso. Es que puede convertirse por esta pseudoespiritualización del impulso o más bien noetización del odio en el animal más cruel y refinado.

La sublimificación revela profundidad psíquica, pues consiste en la sustitución supresiva de los impulsos considerados inferiores y que se enmascaran bajo instancias y apariencias superiores, las cuales resultan ser epifenoménicas o aparienciales. El animal profundo vuélvese así un animal hipócrita, incluso consigo mismo. Este fenómeno es en verdad psicosocial, pues es la imposición de una moral represiva biofóbica. En cambio, el fenómeno de la espiritualización del impulso vital en vez de suprimir el impulso lo facilita y refina adecuada y óptimamente, gracias a formas de la cultura puestas a su favor y que lo intensifican y embellecen tanto en el proceso de su realización como en el momento culminante de su satisfacción en su objeto propio, sin sustitución ninguna ni supresión. En la espiritualización de la 'conducta' la materia sensible se ilumina como campo de expresión del espíritu, pues así es como el espíritu 'conduce' al cuerpo, como la inspiración 'conduce' a la técnica para convertirla en arte, así, del mismo modo, hacer del impulso erótico y de los 
actos del cuerpo la expresión del amor.

Creo que ahondar la espiritualización en la psicodinamia de las motivaciones no sólo es ahondar en la profundidad de animal humano, es también diseñar su verdadero perfil avizorando, así, los niveles más altos. En esta espiritualización de las motivaciones se introduce en el estudio de la psicología los motivos sublimes de la experiencia y de la conducta humanas, el bien, la justicia, la belleza, el amor, el saber, la gentileza, la cortesía, la ternura, el respeto. La espiritualización de las motivaciones permite considerar al animal humano, y en su profundidad y altura, como persona. No se trata de un aparato mental como lo ve el mecanicismo, pero tampoco de un mero organismo psicofísico, determinado o condicionado por factores endógenos, como los hereditarios, los genéticos y exógenos, como los sociales, familiares y educativos. En verdad, la persona está montada sobre un organismo psicofisiológico humano. Es la metáfora del jinete que 'conduce' el comportamiento de la cabalgadura. El hombre 'conduce' a su organismo porque es persona que tiene fines, y fines superiores, sublimes. Es que gracias a la persona como sujeto de la vida psíquica es posible en el animal humano algo nuevo e inusitado en la escala animal: la autodeterminación y la libertad como proyecto intrínseco de autorrealización de la propia existencia. En esto está el quid de la plenitud o del fracaso de la existencia humana. Se trata de la realización o de la frustración de un nivel de existencia superior, el de los motivos sublimes. Creo que el psicólogo tiene que ahondar en el problema de la realización o del fracaso existencial como problema psicológico fundamental. El hombre es el animal que puede espiritualizar su conducta y en la medida en que lo hace es más hombre.

\section{REFERENCIAS}

Alighieri, Dante (1965). Divina comedia. (19a. ed.). Milán: Ulrico Hoepli.

Arcipreste de Hita (1955). Libro del buen amor. Buenos Aires: Losada.

Capellanus, A. (1969). The art of courtly love. New York: Norton.

Cassirer, E. (1956). Philosophie der symbolischen Formen. Londres: Bruno Cassirer Oxford.

Chiappo, L. (1955). Investigación experimental acerca del proceso configurativo noético-perceptivo en los afásicos. Revista de Neuro-psiquiatría, 21, 456458.

Chiappo, L. (1957). Prueba de integración noético-perceptiva en esquizofrénicas crónicas. Anales de la Facultad de Medicina, 40, 108-129.

Chiappo, L. (1958). La evolución verbal categorial en las lesiones cerebrales. Revista de Neuro-psiquiatría, 21, 456481.

Chiappo, L. (1959). The noetic-perceptive configuration test and impairment of the abstract attitude. Journal of Individual Psychology, 15, 93-99. 
Chiappo, L. (1978). Nietzsche, dominación y liberación. Lima.

Chiappo, L. (1983). Dante y la psicología del infierno. Lima: Ausonia, 1983. Reimpresión: Lima, 1983, UPCH.

Chiappo, L. (1997-1998). Ernst Cassirer y el concepto de forma simbólica. Acta Herediana, 22/23.

Chiappo, L. (1987-1990). Escenas de la comedia. 3 vol. Lima: CONCYTEC.

Chiappo, L. (en preparación). La existencia humana. (Acerca de la comedia de Dante).

De Ajuriaguerra, J. Hecaen, H. (1957). Le cortex cerebral. Etude neuropsychopathologique. París: Masson.

Danielou, J. (1953). Mystique de la Ténèbre chez Grégoire de Nysse. En Ch. Baumgartner, (Eds.), Dictionaire de Spiritualité, 2. París: Beauchesne.

Delgado, H. (1915). El psicoanálisis. El Comercio.

Delgado, H. (1938). Psicología general y psicopatología de las tendencias instintivas. Revista de Neuro-psiquiatría, 1, 255-353.

Goldstein, K. (1951). La estructure de l'organisme. París: Gallimard.

Gracián, B. (1941). El criticón. Buenos Aires: Losada.

Heidegger, M. (1957). Sein und Zeit. Tubinga: Niemeyer.

I discorsi di Gotamo Buddho del Majjhima Nijayo. Bari: Laterza \& Figli.

Jaynes, J. (1987). El origen de la conciencia en la ruptura de la mente bicameral. México, DF: Fondo de Cultura Económica.
Laín Entralgo, P. (1958). Mis páginas preferidas. Madrid: Gredos.

Lersch, Ph. (1968). La estructura de la personalidad. Barcelona: Scientia.

Montagne, M. (1941). Ensayos. Buenos Aires: Losada.

Nietzsches Werke. Salzburgo-Stuttgart: Das Burgland-Buch.

San Francisco de Sales (1983). Introducción a la vida devota. Buenos Aires: Dictio.

San Juan de la Cruz (1980). Obras Completas. (10a. ed.). Madrid: Biblioteca de Autores Cristianos.

Spranger, E. (1950). Lebensformen. Tubinga: Niemeyer.

The complete works by William Shakespeare. Londres: Spring Books.

Tomás de Aquino (1947). Suma teológica, (1), Madrid: Biblioteca de Autores Cristianos.

Vernón, P.E. \& Allport, G.W. (1931-1932). A test for personal values. Journal of Abnormal and Social Psychology, 26, 231-248.

Zubiri, X. (1948). Naturaleza, historia, Dios. Buenos Aires: Poblet. 